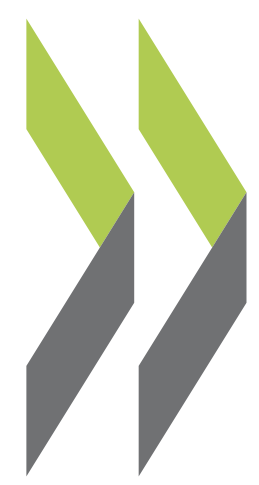

OECD Economics Department Working Papers No. 1078

Improving Fiscal Federal Relations for a Stronger

Aida Caldera Sánchez

Mexico 
Organisation de Coopération et de Développement Économiques

Organisation for Economic Co-operation and Development

23-Aug-2013

ECONOMICS DEPARTMENT

English - Or. English

\title{
IMPROVING FISCAL FEDERAL RELATIONS FOR A STRONGER MEXICO
}

ECONOMICS DEPARTMENT WORKING PAPERS No. 1078

\author{
By Aida Caldera Sánchez
}

All Economic Department Working Papers are available through OECD's Internet website at http://www.oecd.org/eco/Workingpapers

JT03343701

Complete document available on OLIS in its original format

This document and any map included herein are without prejudice to the status of or sovereignty over any territory, to the delimitation of international frontiers and boundaries and to the name of any territory, city or area. 


\section{ABSTRACT/RÉSUMÉ}

\section{Improving fiscal federal relations for a stronger Mexico}

Mexico has achieved a high degree of decentralisation in public services, but the Mexican fiscal federal system has important shortcomings. States and municipalities have become heavily dependent on federal transfers to finance a growing share of public spending. This leaves the burden of raising tax revenues falling almost exclusively on the federal government and reduces incentives for efficient spending and active tax collection at the subnational level. It can also lead to moral hazard and fiscal slippages. The federal government should harden the budget constraint on sub-national governments by limiting further increases in transfers and avoiding extraordinary transfers. Promoting the implementation of stronger fiscal rules, such as rules on deficits and debt ceilings, could also help to harden budget constraints and to ensure greater fiscal discipline. States should be given more taxing powers, if they are to collect a larger share of total revenues. Greater accountability and clarification of spending responsibilities could also contribute to improve the efficiency of spending among states and municipalities.

JEL classification: $\mathrm{H} 11 ; \mathrm{H} 77$; H30; O54.

Key words: Federalism; decentralisation; Mexico; local governments.

This working paper relates to the 2013 OECD Economic Survey of Mexico (www.oecd.org/eco/surveys/Mexico).

\section{Améliorer les relations budgétaires fédérales pour renforcer l'économie Mexicaine}

Le Mexique a poussé très loin la décentralisation des services publics, mais le système budgétaire fédéral présente des déficiences importantes. Les États et les communes sont désormais très tributaires des transferts fédéraux pour financer une part croissante des dépenses publiques. De ce fait, c'est sur l'État fédéral que repose presque exclusivement la tâche de lever l'impôt et l'échelon infranational est peu incité à dépenser efficacement et à recouvrer activement des recettes fiscales. Cette situation peut aussi générer un aléa moral et des dérapages budgétaires. L'État fédéral devrait exercer une plus forte pression budgétaire sur les entités infranationales en limitant les nouvelles hausses des transferts et en s'abstenant de consentir des transferts exceptionnels. L'application de règles budgétaires plus strictes, comme des règles en matière de déficits et le plafonnement de la dette, pourrait aussi accentuer les contraintes et assurer une plus grande discipline dans ce domaine. Pour être en mesure de recouvrer une plus grande partie des recettes publiques totales, les États doivent se voir accorder plus de pouvoirs en matière fiscale. Davantage de responsabilisation et une clarification des attributions sur le plan des dépenses seraient aussi de nature à améliorer l'efficience de ces dernières au niveau des États et des communes.

Classification JEL : H11; H77 ; H30 ; O54.

Mots clés : Le fédéralisme ; la décentralisation ; le Mexique ; les gouvernements locaux.

Ce document de travail se rapporte à l'Étude économique de l'OCDE du Mexique 2013 (www.oecd.org/eco/etudes/Mexique).

You can copy, download or print OECD content for your own use, and you can include excerpts from OECD publications, databases and multimedia products in your own documents, presentations, blogs, websites and teaching materials, provided that suitable acknowledgment of OECD as source and copyright owner is given. All requests for commercial use and translation rights should be submitted to rights@oecd.org. 


\section{TABLE OF CONTENTS}

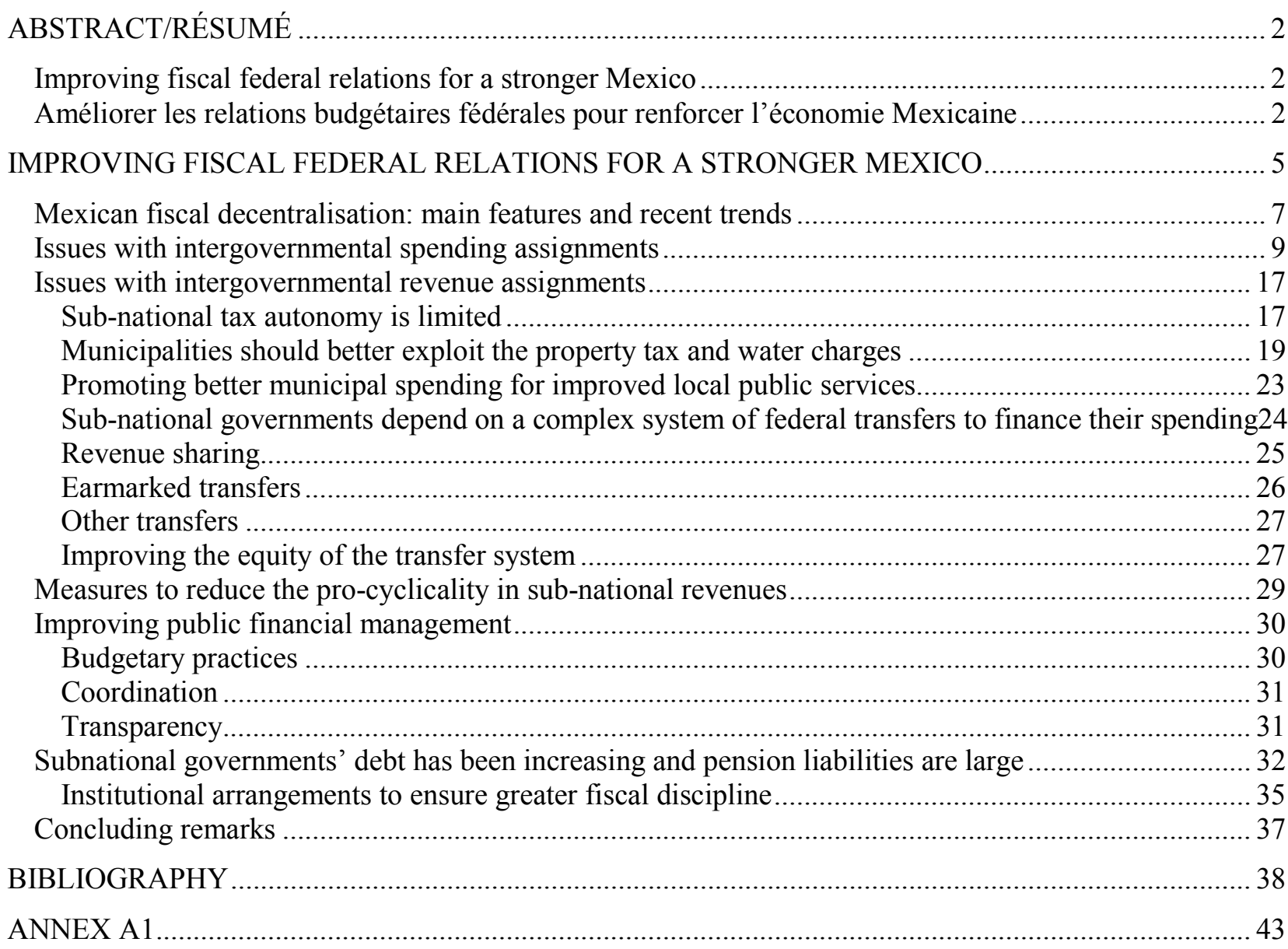

\section{Tables}

1. Allocation of government responsibilities for key public services ............................................... 10

A1.1. Non-earmarked transfers (Participaciones federales, Ramo 28) …........................................... 43

A1.2: Earmarked transfers (Aportaciones federales, Ramo 33) ............................................................. 44

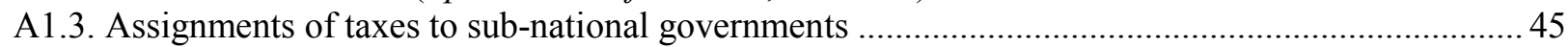

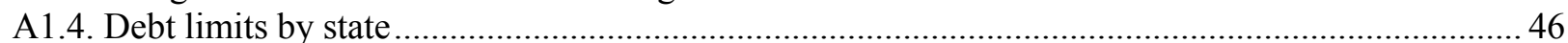

\section{Figures}

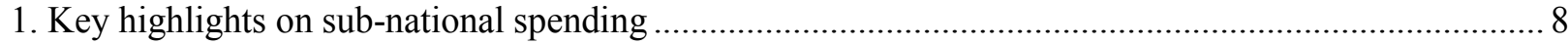

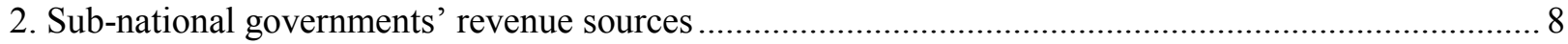

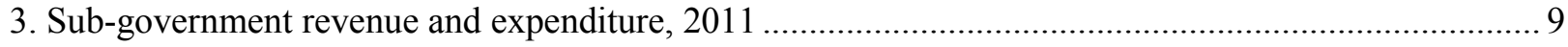

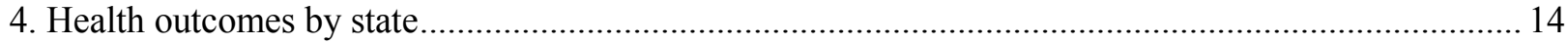

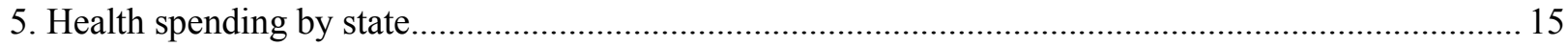

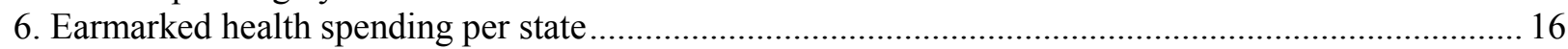




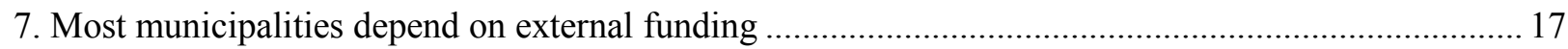

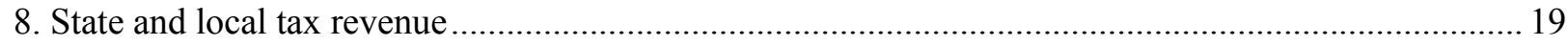

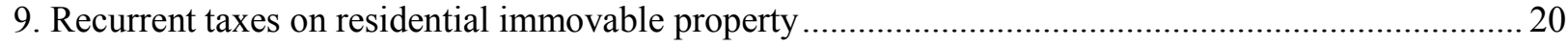

10. Unit price of water and sanitation services to households including taxes ................................... 22

11. Transfers are not equalising and may reduce local tax effort.......................................................... 25

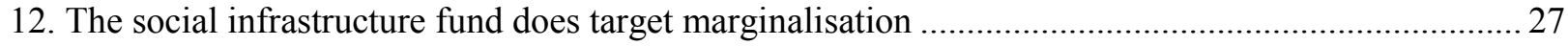

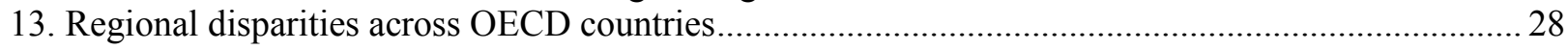

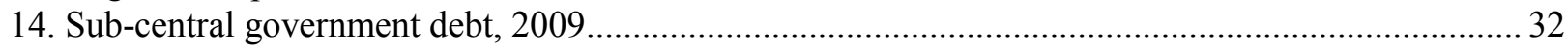

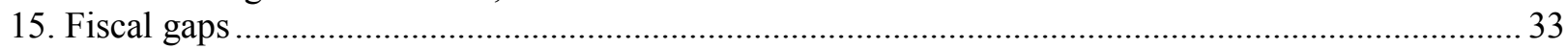

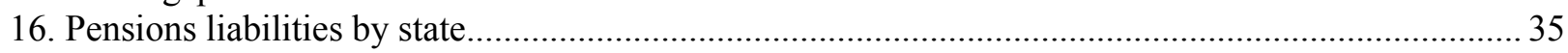

\section{Boxes}

Box 1. What are the characteristics of good intergovernmental fiscal arrangements?............................. 6

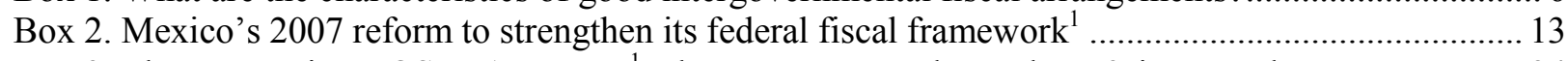

Box 3. The Norwegian KOSTRA system: ${ }^{1}$ what gets measured gets done \& improved .......................... 24

Box 4. An assessment of the stabilisation properties of the Mexican intergovernmental transfer system 29

Box 5. Recommendations to improve fiscal relations across levels of government ................................ 38

The statistical data for Israel are supplied by and under the responsibility of the relevant Israeli authorities. The use of such data by the OECD is without prejudice to the status of the Golan Heights, East Jerusalem and Israeli settlements in the West Bank under the terms of international law. 
ECO/WKP(2013)70

\section{IMPROVING FISCAL FEDERAL RELATIONS FOR A STRONGER MEXICO}

\section{By Aida Caldera Sánchez ${ }^{1}$}

During the 1990s Mexico embarked on a process of decentralisation of core expenditure responsibilities to its states and, to a lesser extent, municipalities. Two decades later, although Mexico has achieved a high degree of decentralisation in public services, the Mexican federal system has some shortcomings. States, and to less extent municipalities, have formal responsibilities over major categories of spending, including in key areas such as health and education, and account for almost half of government spending. But decentralisation has not met the objective of more efficient and effective public service delivery, as it was supposed to. Neither have the wide regional disparities in public services narrowed.

Given shared responsibilities for implementation and finance across the three levels of government, there is great scope for duplication, wasteful use of resources and avoidance of responsibility for outcomes. This may also be hindering investment, despite Mexico's significant spending needs. Many subnational governments also have perverse incentives. Because most of their spending is funded by federal transfers, subnationals have little incentive to spend wisely and be fiscally prudent. Such great disparity between spending and own-revenues may also be deterring own-revenue generation at the subnational level, given the political cost of collecting taxes and the resources needed to administer them. Because information on the use of sub-national governments' financial resources is scant and monitoring infrequent, it is also hard to evaluate sub-national governments' performance in the provision of public services.

These factors reduce public sector efficiency and more broadly the efficient use of resources that are essential for the Mexican economy to develop and grow. With slow growth and large economic disparities, Mexico needs to spend wisely to address its human capital, health and infrastructure gaps and enhance its growth potential. With a larger degree of revenue autonomy and lower reliance on federal transfers, Mexican sub-national governments would have greater incentives to spend more efficiently and promote growth. Nationwide, better coordination of fiscal policies between the federal and the sub-national governments, which is currently weak, could further contribute to strengthen Mexico's macroeconomic stability and its ability to withstand shocks. Greater control of sub-nationals' borrowing could also help to ensure greater fiscal discipline at the sub-national level. Since the 1994-95 financial crisis, subnationals'debt has remained relatively low, but it has recently been on a rising trend.

1. Economist in the OECD Economics Department, email: aida.calderasanchez@oecd.org. This paper was prepared for the OECD Economic Survey of Mexico published in May 2013 under the authority of the Economic and Development Review Committee. The paper usefully benefited from comments from Aziza Akhmouch, Rodrigo Barrios, Hansjörg Blöchliger, Bert Brys, Andrew Dean, Sean Dougherty, Robert Ford, Jacobo Garcia Villarreal, Celine Kauffmann, Xavier Leflaive, Patrick Lenain, Javier Sánchez Reaza, Bill Tompson, Diana Toledo Figueroa, Miguel Messmacher, Anna Pons, Ernesto Revilla and Richard Yelland. Special thanks are due to Roselyne Jamin for helpful research assistance and to Deirdre Claassen for editorial support. 
The chapter assesses the sources of distortions of the current system of fiscal federal relations, and recommends reforms that would improve its efficiency and equity. To do so, it benchmarks Mexico's system of fiscal federalism against a few key principles defining good intergovernmental fiscal arrangements (Box 1) and builds on international experience in the reform of fiscal federal relations systems in other OECD countries to provide recommendations to improve the system.

\section{Box 1. What are the characteristics of good intergovernmental fiscal arrangements?}

The answer is far from simple. There is no single "correct" model for the design of intergovernmental fiscal arrangements. Fiscal relations in federal countries are much more often shaped by historical, political, and social factors than by economic considerations. Countries often face trade-offs between efficiency and redistribution when designing or reforming their arrangements, and the weight they give to each of these objectives often depends on a complex matrix of variables. Apart from choices about the distribution of tax and spending responsibilities, countries also need to take into account macroeconomic constraints, as well as relevant institutional factors, such as constitutional or political constraints, or the capacity of local governments to spend well and raise their own revenues. Reforms are also often complicated by vested interests and possible winners and losers reforms may entail.

Despite very different country experiences, some general principles can be drawn from the considerable amount of work, international organisations, including the $\mathrm{OECD}^{1}$, and the academic literature (e.g. Ahmad and Brosio, 2006; Warren, 2006; Boadway and Shah, 2009) have devoted to analyse different country experiences and to assess how best to design fiscal federalism arrangements and reform the systems already in place.

\section{Assignment of expenditure responsibilities}

Subsidiarity: Sub-national governments should be responsible for those services whose benefits are confined primarily to their geographic area and for which residents should have a choice over the quantity and the quality of the service. This will have efficiency gains by leading to greater accountability and by introducing competition among jurisdictions, and thus greater public sector efficiency.

Transparency of expenditure responsibilities: When expenditure responsibilities are shared among jurisdictions, responsibilities of each level of government should be clear, to enhance accountability. And appropriate coordination mechanism should be in place to ensure an efficient use of resources. Overlapping responsibilities can weaken accountability and create an upward bias in spending.

\section{Tax assignments}

Matching revenue-raising powers to spending responsibilities: Tax assignments should follow expenditure responsibilities, so the supply of public goods matches local citizens' preferences and willingness to pay, and hence for sub-nationals to be held accountable and be fiscally responsible.

Efficiency of the tax system: Few taxing powers can be transferred to sub-national governments without raising efficiency and/or distributional concerns. Therefore potential welfare gains from increasing local tax revenues should be weighed against such risks.

Fiscal autonomy and sustainability: Local governments should have autonomy over tax rates and bases. However, to avoid perverse tax competition, leading to a more complex tax system, federally defined bands are advisable. Local tax revenues should be robust and able to expand in line with expenditure needs. However, for countries with significant devolution of spending responsibilities own revenues may not be enough, given the limited scope for fiscal autonomy at the sub-national level, and there is often a need for transfers from the centre.

\section{Intergovernmental transfers}

Adequate funding: The transfer system should provide appropriate funding for subnational operations, while ensuring an adequate level of equalization without blunting incentives to pursue sound policies.

Equity: Sub-national governments with equal fiscal needs should be treated equally. Ideally redistribution should be separated from tax incentives for the sake of transparency. 
Predictability and flexibility: Sub-national governments need to be able to budget and plan for the future, but at the same time, have the flexibility to respond to changing circumstances. Transfers should be formula based rather than discretionary, but have an element of flexibility. Transfers can provide stability and contribute to smooth cyclical shocks, but care must be taken to maintain appropriate incentives for fiscal discipline.

Simplicity and transparency: The transfer mechanism or allocation formula should be readily understandable and easy to administer.

Autonomy: Sub-national governments should have the independence to set priorities and manage services to respond to local needs.

Neutrality of intergovernmental transfers: Sub-national governments should not be able to influence the transfers they receive by manipulating their expenditure or tax decisions. And the transfer mechanism should not penalise subnational governments for sound economic management.

\section{Sub-national governments' fiscal strategies and overall macroeconomic objectives}

Coordination: To ensure consistency with national macroeconomic objectives, it is important to coordinate budgetary policies across government levels.

Control: Fiscal decentralisation can contribute to weaken fiscal discipline. It is therefore important to promote adherence by sub-national governments to national fiscal objectives. Controls on sub-national borrowing and/or effective intergovernmental cooperation mechanisms are often needed for both short-term fiscal stabilization and medium-term fiscal sustainability. To enforce any form of control, availability of relevant fiscal information is crucial, including debt and contingent liabilities.

1. Several OECD Economic Surveys have included chapters devoted to fiscal federalism (Germany, 1999 and 2003; United States and Mexico, 2005; Austria, 2006; Australia, Belgium and Italy 2007). The OECD's “Network on Fiscal Relations across Levels of Government" regularly carries out analysis on a wide range of topics on the relationship between central and sub-central governments, and its impact on efficiency, equity and macroeconomic stability, for both federal and unitary countries.

\section{Mexican fiscal decentralisation: main features and recent trends}

Mexico is a federal country with a three-tier government structure. ${ }^{2}$ It is divided into 31 sovereign states and one federal district. Each state is composed of municipalities, about 2457 of them in the whole country which, while having sovereign autonomy over their political and fiscal development, play a very small role compared to other OECD countries, focusing on the provision of local services such as waste management or water supply.

In the last two decades Mexico has experienced a trend - similar to the rest of the world - towards greater decentralization of spending responsibilities to its states and, to lesser extent, municipalities. As a result, sub-national spending rose sharply from the mid-1980s onwards, both as a ratio of GDP and as a share of overall public spending (Figure 1). The jump was substantial after the changes to the fiscal coordination law in 1998, whereby sub-national governments became responsible, notably, for the provision of education. In 1990, states and municipalities together accounted for 10\% of Mexico's public spending. By 2009, their share of spending had multiplied by four. The increase in spending was matched with greater federal earmarked transfers. Decentralisation has been particularly pronounced in social spending in particular in education, health and poverty alleviation (Figure 1). States do most of the decentralised spending. By contrast municipalities' outlays amount to only $9 \%$ of total public expenditure and are concentrated on the provision of local services and education.

2. Throughout the paper, sub-national/sub-central governments refer to both states and municipalities. Whenever the text refers to an entity (federal, state, municipalities) in particular it is spelled out. 
Figure 1. Key highlights on sub-national spending ${ }^{1}$

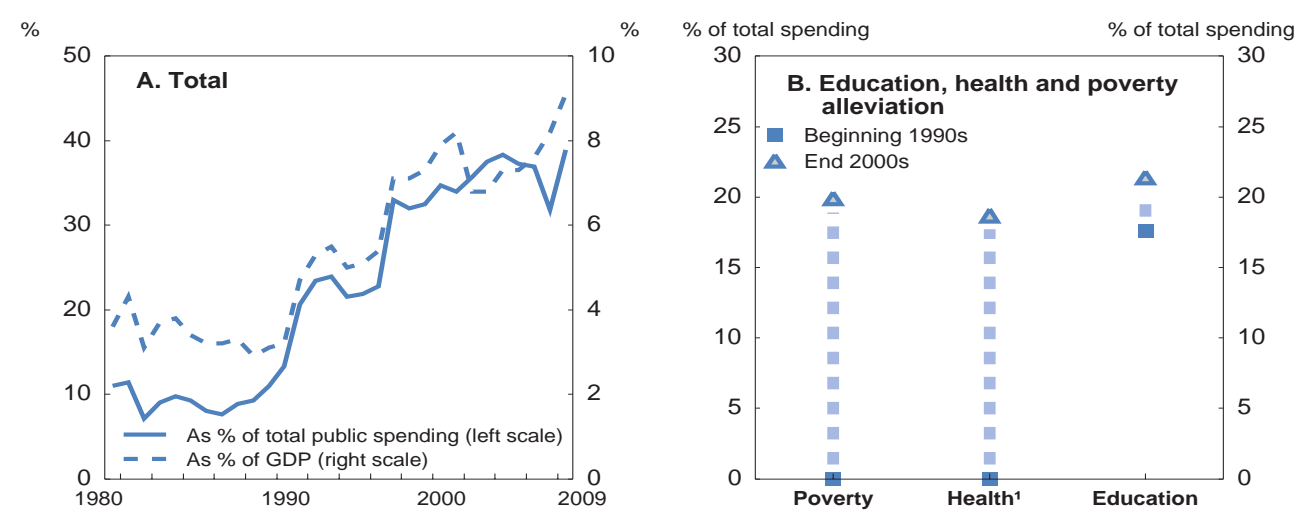

1. Health spending refers to the share of sub-national spending in total public spending for the non-insured population.

2. Source: Quinto informe de gobierno 2011; Centro de Estudios de las Finanzas Públicas, Cámara de Diputados, 1980-2002; OECD, Fiscal Decentralisation database, 2003-2009.

The decentralisation of spending has not been mirrored on the subnational tax revenue side, though it was mirrored by federal transfers. Sub-national governments' own-source revenue, for both states and municipalities, account for a tiny share of total tax revenues, approximately $3 \%$, and represented only $0.7 \%$ of 2009 GDP (Figure 2). By comparison, in the United States, these ratios amounted to $38 \%$ of total tax revenues and 9\% of GDP, while in Canada, they accounted for about 49\% and 16\%. Between 1980 and 1990 most taxing powers were devolved from subnational governments to the federal government. States and municipalities kept full autonomy to set their own tax rates and/or bases over the payroll tax, vehicle taxes, property taxes, and user fees. States are responsible for tax collection for small tax payers (REPECOS). All other taxes, with the largest tax bases, were assigned to the federal government that administers them and shares them with sub-national governments through revenue sharing. Since 1990, states have gone from raising $32 \%$ of their total resources to generating about $10 \%$ on average. For municipalities, the share of own raised revenues declined from $33 \%$ to $19 \%$ on average over the same period (Castañeda and Pardinas, 2012).

Figure 2. Sub-national governments' revenue sources
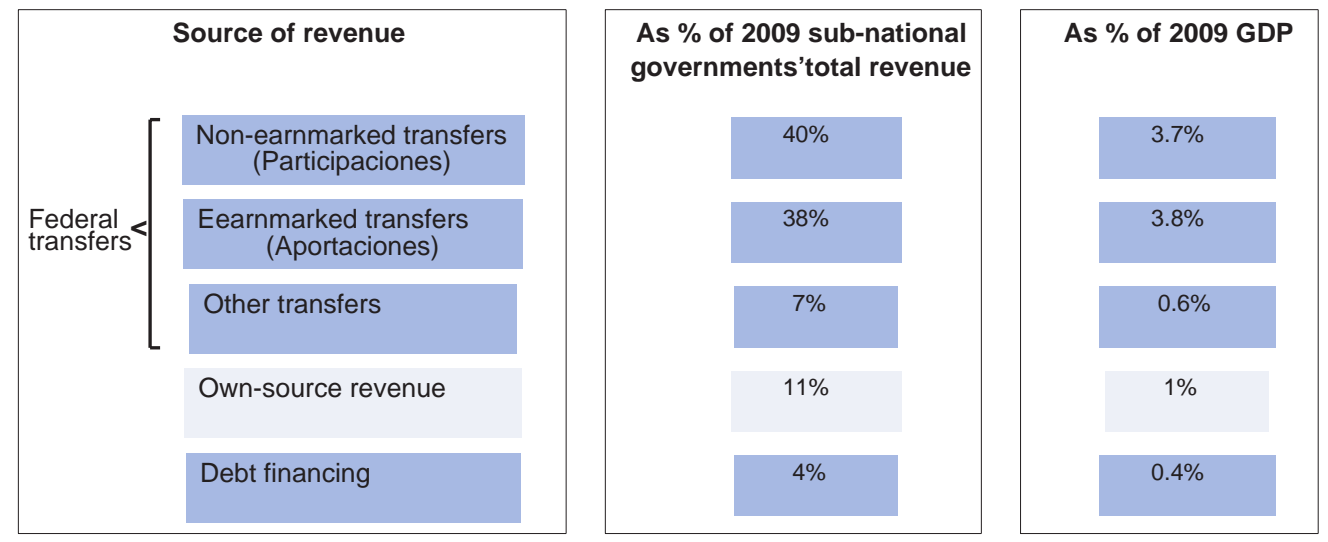

Source: OECD analysis based on Revilla (2010).

Mexican sub-national entities are therefore very far from fully self-financing their spending, in contrast to other federations like United States or Canada (Figure 3). The gap between their spending 
assignments and their own resources is met by large federal transfers, which amounted to $10 \%$ of GDP in 2009 , or an average of over $85 \%$ of subnational governments' total revenues.

The most important type of federal transfers are revenue sharing transfers (participaciones) (see Figure 2), which are non-earmarked and formula based. They consist of a set of eight funds that vary in size and are itemized in the line-item Ramo 28 of the federal budget, along with transfers to compensate states for collecting federal taxes (incentivos). Such participaciones are the largest item in the federal budget. The second most important category of transfers is earmarked transfers (aportaciones) (see Figure 2), to finance the decentralisation of education and health, as well as other local responsibilities, like security. Some of these earmarked transfers have a more or less explicit equalisation role, but these are only about $10 \%$ of all transferred revenue (or $0.7 \%$ of GDP). There are also other transfers of much smaller size. These include matching transfers (convenios) to finance some regional spending, like co-financing of agriculture spending.

Figure 3. Sub-government revenue and expenditure, 2011'

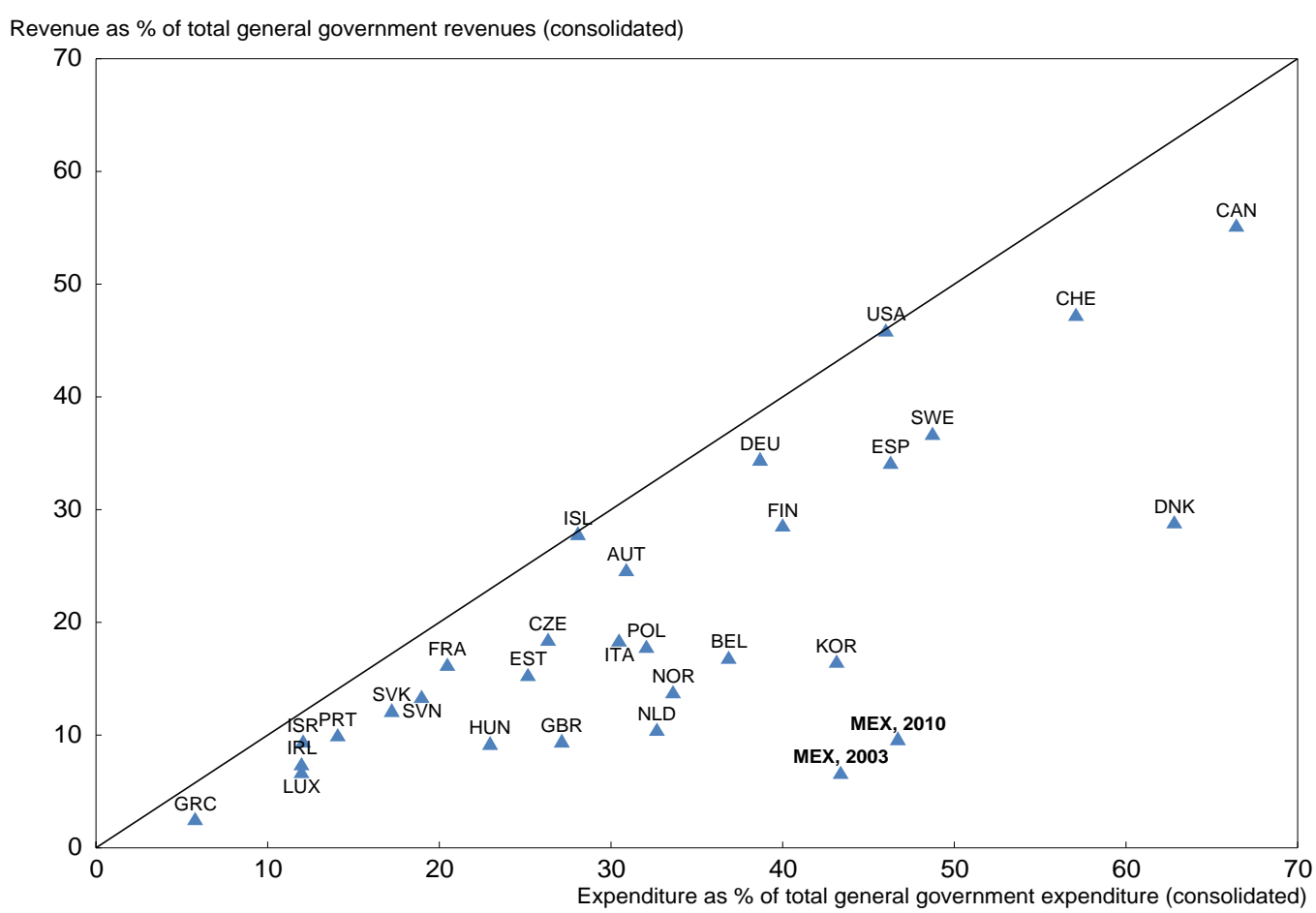

1. 2010 for Canada, Korea and Mexico.

Source: OECD Fiscal Decentralisation Database.

\section{Issues with intergovernmental spending assignments}

\section{Reducing overlapping responsibilities to ensure greater spending efficiency and accountability}

Mexico's public expenditure is characterised by shared responsibilities for implementation and finance across the three levels of government, which make for a system of quite complex overlapping competencies. The federal government is responsible for matters relevant for the whole country, such as macroeconomic policy, defence and R\&D policy; while the states are responsible for the delivery of education and health. However, states are also co-responsible, together with the federal government and municipalities, for poverty alleviation and water management (Table 1). Municipalities are purely responsible for local matters such as water distribution, road maintenance and sometimes public lighting, 
and are co-responsible for school building and implementation of social programmes with the federal and state government. Investment in infrastructure and transportation is another area where spending involves all three layers of government (Table 1).

Table 1. Allocation of government responsibilities for key public services

\begin{tabular}{|c|c|c|c|}
\hline Public services & Central government & States & Municipalities \\
\hline \multirow{2}{*}{ Health } & $\begin{array}{l}\text { Regulations, standards and } \\
\text { quality controls. Negotiation of } \\
\text { salaries and employment } \\
\text { conditions }\end{array}$ & $\begin{array}{l}\text { Organisation and operation of health } \\
\text { care services for non-insured } \\
\text { population. Responsible for primary } \\
\text { care for both rural and urban poor. }\end{array}$ & \\
\hline & $\begin{array}{l}\text { Financing of hospital } \\
\text { infrastructure. } \\
\text { Financing and operation of all } \\
\text { hospitals belonging to the } \\
\text { federal social security systems } \\
\text { (IMSS, ISSSTE). }\end{array}$ & $\begin{array}{l}\text { Administration and maintenance of } \\
\text { hospitals for primary care that used to } \\
\text { be operated by the federal Ministry of } \\
\text { Health, as well as some state owned } \\
\text { hospitals (for all care levels). }\end{array}$ & \\
\hline \multirow[t]{2}{*}{ Education } & $\begin{array}{l}\text { Controls plans, programmes of } \\
\text { study, assessment of education } \\
\text { outcomes; training of teachers; } \\
\text { determines teachers' salaries; } \\
\text { teachers' training and } \\
\text { evaluation; financing of } \\
\text { education through transfers }\end{array}$ & $\begin{array}{l}\text { Operation of basic education (pre- } \\
\text { school, primary and secondary levels), } \\
\text { teachers' training colleges and } \\
\text { indigenous and special education. } \\
\text { Building new infrastructure. Set-up } \\
\text { supervision systems }\end{array}$ & $\begin{array}{l}\text { Co-financing with other } \\
\text { government levels and } \\
\text { maintenance of primary } \\
\text { schools and some } \\
\text { construction concurrent with } \\
\text { the state }\end{array}$ \\
\hline & $\begin{array}{l}\text { Financing of university } \\
\text { infrastructure }\end{array}$ & Maintenance of universities & \\
\hline $\begin{array}{l}\text { Anti-poverty } \\
\text { programmes }\end{array}$ & Funding of social programmes & $\begin{array}{l}\text { Implementation of social programmes } \\
\text { in coordination with Sedesol }\end{array}$ & $\begin{array}{l}\text { Implementation of social } \\
\text { programmes }\end{array}$ \\
\hline Water & $\begin{array}{l}\text { Owner of water resources, with } \\
\text { the right to transfer titles to } \\
\text { other parties. Co-financing of } \\
\text { water infrastructure. Sets norms } \\
\text { for compulsory standards for } \\
\text { technical and operational } \\
\text { aspects. }\end{array}$ & $\begin{array}{l}\text { Tariff setting (through State congress or } \\
\text { water commission); co-financing of } \\
\text { water infrastructure; set state-level } \\
\text { regulation, including tariffs, design } \\
\text { criteria for water infrastructure } \\
\text { construction, environmental and health } \\
\text { standards for water infrastructure. } \\
\text { Planning and developing big water } \\
\text { infrastructures. }\end{array}$ & $\begin{array}{l}\text { Water distribution, drainage } \\
\text { and sewerage system (also } \\
\text { public lightening, garbage } \\
\text { collection, public markets, } \\
\text { public safety, cemeteries and } \\
\text { public parks) }\end{array}$ \\
\hline $\begin{array}{l}\text { Infrastructures } \\
\text { and } \\
\text { transportation }\end{array}$ & \multicolumn{3}{|c|}{$\begin{array}{l}\text { Road construction and maintenance are split between the three levels, with the construction mainly } \\
\text { executed by federal and state governments, and maintenance mainly being done by the state or } \\
\text { municipalities. Parks and public transportation are split with all levels of government providing services that } \\
\text { correspond to their geographic area, with public transportation only rarely being managed by } \\
\text { municipalities. }\end{array}$} \\
\hline
\end{tabular}

Source: Author analysis based on Cabrera Castellanos et al (2008), OECD (2012a); Cabrero and Martínez-Vázquez, (2000); Fernández Martínez (2011); Martínez-Fritscher and Rodríguez-Zamora (2011).

Federal transfers finance the bulk of sub-national expenditure, in particular in the areas of health and education, as discussed above. But given overlapping responsibilities and very little information on spending patterns, sub-national governments have few incentives to be fully accountable for the provision of services and there is great scope for blame shifting between the federal and sub-national governments. This potentially results in poor cost-efficiency in the provision of public services and undermines service quality. Overlapping spending responsibilities give also little incentive to exploit some of the benefits of greater decentralisation, such as innovation in management to suit local needs, as sub-national governments are not fully accountable for the provision of services.

In theory, a number of principles guide the allocation of functions across government levels and overlapping of responsibilities should be minimized for fiscal decentralisation to be effective (IMF, 1997). However, in practice establishing clear cut divisions is rather difficult and in most countries there is some 
degree of overlap (Joumard and Kongsrud, 2003). Rather than seeking a complete reorganisation of assignments to achieve an optimal allocation of spending functions, Mexico should seek instead to clarify spending responsibilities for each level of government. This would be particularly useful in the areas of education and health, which account for the lion's share of regional spending, and where there is also a substantial degree of overlap, as discussed below.

\section{Education}

Mexico has achieved significant progress in improving the coverage and quality of its education system. However, education performance, as measured by the PISA test, remains below other OECD countries (OECD, 2011a). Disparities across states in education outcomes are also wide. For instance, PISA tests for student performance tend to correlate strongly with socioeconomic background and income per capita across states (CONEVAL, 2011; Schwellnus, 2009). Such disparities can exacerbate and lead to a perpetuation of income differences across generations and regions. Increasing the efficiency of education spending by reducing overlaps and improving its targeting, as described below, could contribute to reduce education disparities across states and thereby to stronger economic growth. It could also help to meet the financial challenge that Mexico faces to make upper secondary education compulsory from the school year 2012-2013 and reaching universal coverage by 2021-22.

While the federal government is the main decision maker in the national education system, states are in charge of the operation of basic education services and execute most education spending. Despite education responsibilities being relatively clearly defined formally, in practice state and federal responsibilities sometimes overlap and all three levels of government have simultaneous obligations for important services. For instance, in about a third of all states there are both federal and state institutions in charge of similar tasks (OECD, 2010a; Fierro Evans et al. 2009). Another example is the funding of schools and universities. Municipalities are sometimes responsible for maintaining school buildings, while federal and state governments do most of the investment and maintenance. In the case of universities, the federal government finances the infrastructure, while the states are responsible for maintenance, even though there are federal transfers to support universities' current expenses. This can lead to lack of action or duplication and raise concerns on efficiency and accountability (OECD, 2013a). Each level of government can blame the other for not doing its part, resulting in under-provision of education services and poor cost efficiency. There should be greater clarification of states' and municipalities' functional and spending responsibilities in education. And responsibility for new infrastructure and its maintenance should be kept at the same government level.

Higher state autonomy in the management of education spending could also contribute to greater spending efficiency and better outcomes. Funding to schools is mainly provided through a large number of federal and state programmes which, for example, amount to 140 in the state of Puebla (OECD, 2013a). Such a large number of programmes raise efficiency concerns, both on its bureaucratic costs and matching difficulties. It also leads to equity concerns. Schools need to apply in order to get the resources, but, many of the smallest and poorest schools do not have the administrative capacity to complete the application process or handle the reporting requirements (OECD, 2010a; OECD, 2013a). Mexico could consider rationalising the number of programmes and providing states with more autonomy to restructure them in order to provide a better matching between programmes and school needs (OECD, 2013a). On the other hand, the perception of a soft budget constraint has sometimes led to unsustainable increases in states' expenditure on education, particularly personnel costs.

States have primary responsibility over staffing and funding, but they have little flexibility in the way money is spent as most of the funding is earmarked for the payment of salaries. Indeed, staff compensation absorbs over $90 \%$ of all education spending, much above other OECD and Latin American countries. This leaves little room for investment in other education inputs, such as teaching materials, teachers' training 
and school infrastructure, which are key for good education outcomes (Schwellnus, 2009). A further sideeffect of insufficient funding for non-wage expenses is that schools rely on parent donations to cover financing gaps, which represent a significant proportion of the school budget (Campos et al., 2010). This leads to great discrepancies between resources available to schools in rich versus poor communities leading to inequitable education opportunities (OECD, 2010a; OECD, 2013a).

The wage negotiation system clearly contributes to high wages. States employ teachers, but their job status and pay conditions are decided in a two-step procedure. A first negotiation takes place at the federal level by the very powerful teachers union and the federal government, who often settle for large annual pay increases (Villanueva Sánchez, 2010). This highly centralised approach not only limits states' autonomy in the management of human resources, but also contributes to wage increases that are not linked to any type of evaluation or quality of teaching. The national wage negotiation between the federal government and the union is followed by a second negotiation between the state and the regional representatives of the teachers union. This second round grants additional wage increases on top of those negotiated at the national level. There should be a unique wage negotiation in order to reduce pressures on education budgets.

Education spending also needs to be targeted more effectively to education needs to reduce differences in education outcomes across states and enhance education performance. The distribution of the main earmarked transfer for education (Fondo de Aportaciones para la Educación Básica, FAEB) penalises poor against richer states doing little to reduce education inequalities, notwithstanding some recent improvements (Schwellnus, 2009). Until 2007, the FAEB transfer was based on a formula driven by supply factors (number of schools and teachers) and cost shares in place prior to the decentralisation of education in 1998. Such criteria gave incentives to increase the number of schools and teachers at the expense of other education inputs. It also discriminated against poorer states as richer states had developed their own education systems before education was decentralised. And this perpetuated inequities in the education system (Joumard, 2005).

A fiscal reform in 2007 (Box 2) changed the redistribution formula. Allocation is now based on demand (number of students), state co-financing of education, and education quality (Annex Table A1.2). The overall objective is equalizing transfers per students among states over time, which is welcome. Including quality in the formula is also welcome, as it gives states incentives to improve outcomes in order to receive more funding. However, no clear and transparent rules have been established to define education quality (Villanueva Sánchez, 2010). Including state education spending in the formula could also penalise poorer states, where needs for additional resources are larger, and limit the redistributive features of the transfer. To further improve the targeting of education spending and improve education outcomes, the allocation criteria for the FAEB fund should be revised. Education quality should be granted a higher weight in the formula and be based on a broadly agreed and transparent definition of education quality, in order to promote better education outcomes. Rather than basing the allocation of the transfer on states' spending efforts, which can penalise poor states over richer ones, it should also be based on the number of students and quality, as well as include equity criteria to account for the existing cost differentials and socio-economic disparities across states. 


\section{Box 2. Mexico's 2007 reform to strengthen its federal fiscal framework ${ }^{1}$}

Mexico carried out a public finance reform in 2007. The reform had four main objectives, among which was strengthening Mexico's federal fiscal framework. The first, and most important objective, was to increase Mexico's meagre tax revenues. Secondly, the reform aimed at establishing a better institutional structure for more efficient and transparent public spending. Thirdly, the objective was to improve the tax administration. And finally, the reform aimed to strengthen the federal fiscal framework. The reforms to the federal fiscal framework focused on two core areas of the system that were causing inefficiencies.

First, the reform aimed to give sub-national entities more taxing powers and the incentives to use them, without jeopardizing federal public finances, and while avoiding a proliferation of distortive or inefficient local taxes. For that purpose states were allocated new tax powers. First, states can tax the final sale of a certain subset of goods currently taxed by the federation with a special production tax (IEPS). Second, a new tax on gasoline and diesel collected and administered by the states, and with the base and rate set by the federal government, was introduced. Third, the federation transferred the power over the vehicle tax (tenencia) to the states by 2012. The creation of a sales tax was proposed but not approved.

Second, the reform aimed to simplify and improve the incentives embedded in the formulas for the distribution of federal transfers. For that purpose, the reform modified the allocation formula for the Fondo General de Participaciones, the largest of all federal transfers (Annex Table A1.1). Before 2007, the fund was distributed to states on an equal per capita basis $(45.17 \%)$, on the basis of actual efforts to raise federally coordinated excise taxes $(45.17 \%)$, and the remaining $(9.66 \%)$ according to a redistributive coefficient giving favourable treatment to states with few inhabitants and lower tax revenues. One crucial problem with the formula was that it pursued two contradictory objectives: first, to compensate states for relinquishing their tax powers and give incentives for higher local revenue and economic activity; second, redistribution. Neither of them was achieved.

Since 2008 a new formula seeks to strengthen incentives to increase local tax efforts and local economic activity linking federal transfers directly to population, growth in economic activity and local tax collection levels (Annex Table A1.1). However, the allocation of non-earmarked transfers does not yet seem to follow the new criteria but rather pre-reform allocations, possibly because the hold-harmless clause included in the new formula implies a long transition period.

To improve the redistributive features of the system, the reform also modified the formulas of two of the eight earmarked transfers to provide more resources to states with greater needs. The fund earmarked to education (FAEB), which is the most important earmarked transfer accounting for $60 \%$ of all targeted transfers, changed its redistribution formula (Annex Table 3.A1.2). It now seeks to equalise federal transfers per student across states and distribute according to demand (number of students) rather than supply (teachers' payroll). A smaller fund, the FAFEF, which did not previously have a formula, is now distributed based on inverse GDP per capita, with the objective of fostering local development. In all three cases, so no state would lose out from the reform, the new formulas included a holdharmless clause that froze in nominal terms the transfers received by each state at 2007 pre-reform levels, and applied the new formula to any increase in transfers.

1. Description of the reform based on González Anaya and Revilla (2012) and presentations from Mexico's Ministry of Finance.

There are large economic disparities between states, for instance differences in sub-central GDP per capita, are the largest among OECD countries and have increased over time (OECD, 2012a). Moreover, disparities are substantial across Mexican states in terms of indigenous populations, whom are characterised by worse health and education outcomes (UNPD, 2011). Other states have a difficult topography with population being dispersed in small communities, leading to relatively higher costs of service provision. Funding formulas should be revised so that states with a large share of schools serving the most disadvantaged areas receive more money per student (OECD, 2012). Policies aimed at improving human capital in disadvantaged regions not only make sense from an equity perspective, but also from an efficiency one. The key drivers of growth vary according to a region's level of development, but education and training, above all, are critical for the growth of all regions (OECD, 2012f).

Finally, there is segmentation and lack of information on spending patterns, which renders the targeting of spending and the monitoring and evaluation of education programmes extremely difficult. For instance, spending on wages, number of teachers and registered students are not correctly, or homogenously, accounted for across states (IMCO, 2010; Auditoría Superior de la Federación, 2008). This is a big problem, not least because the earmarked transfer for education is allocated to states based on the 
number of students. More broadly, such lack of information makes the assessment of the optimal level of state spending extremely difficult, including whether resources are used properly. The recent federal announcement to create a census of schools, teachers and students is a step forward. The information system should facilitate keeping track of individual student and teacher trajectories and reporting on inequities in learning outcomes of different student groups (Santiago et al., 2012). Data on parents' contributions to public schools should also be collected, as currently there is no account of its actual extent despite its significance (OECD, 2013). Finally, there is room to better exploit system-level information to improve evaluation and policy planning of education services and states could play a greater role in setting up and supporting local school and teacher evaluation systems.

\section{Health}

Health is the second area where the decentralization of responsibilities to states has been most significant. While the core of the Mexican health system remains centralized, with the federal government setting the policy framework, states are responsible for the organization and operation of health care services for the non-insured population and for providing care to the rural and urban poor (see Table 1). At the macro level, health indicators have shown significant improvements over the past decades, although they remain behind most OECD countries (Joumard et al., 2010). Disparities in health outcomes and financial resources across regions are wide, but have decreased, with poorer regions having fewer resources and worse outcomes (Figures 4 and 5). There are also concerns about the efficiency and transparency of public spending. Further exploiting efficiency gains in health spending would allow improving outcomes further. It would also contribute to the savings Mexico will need to meet its rapidly growing health care demand. As population ages, public health spending will increase by 2.1 percentage points between 2010 and 2030 according to OECD projections (De la Maisonneuve and Oliveira Martins, 2013), from $2.5 \%$ of GDP to $4.6 \%$.

Figure 4. Health outcomes by state ${ }^{1}$
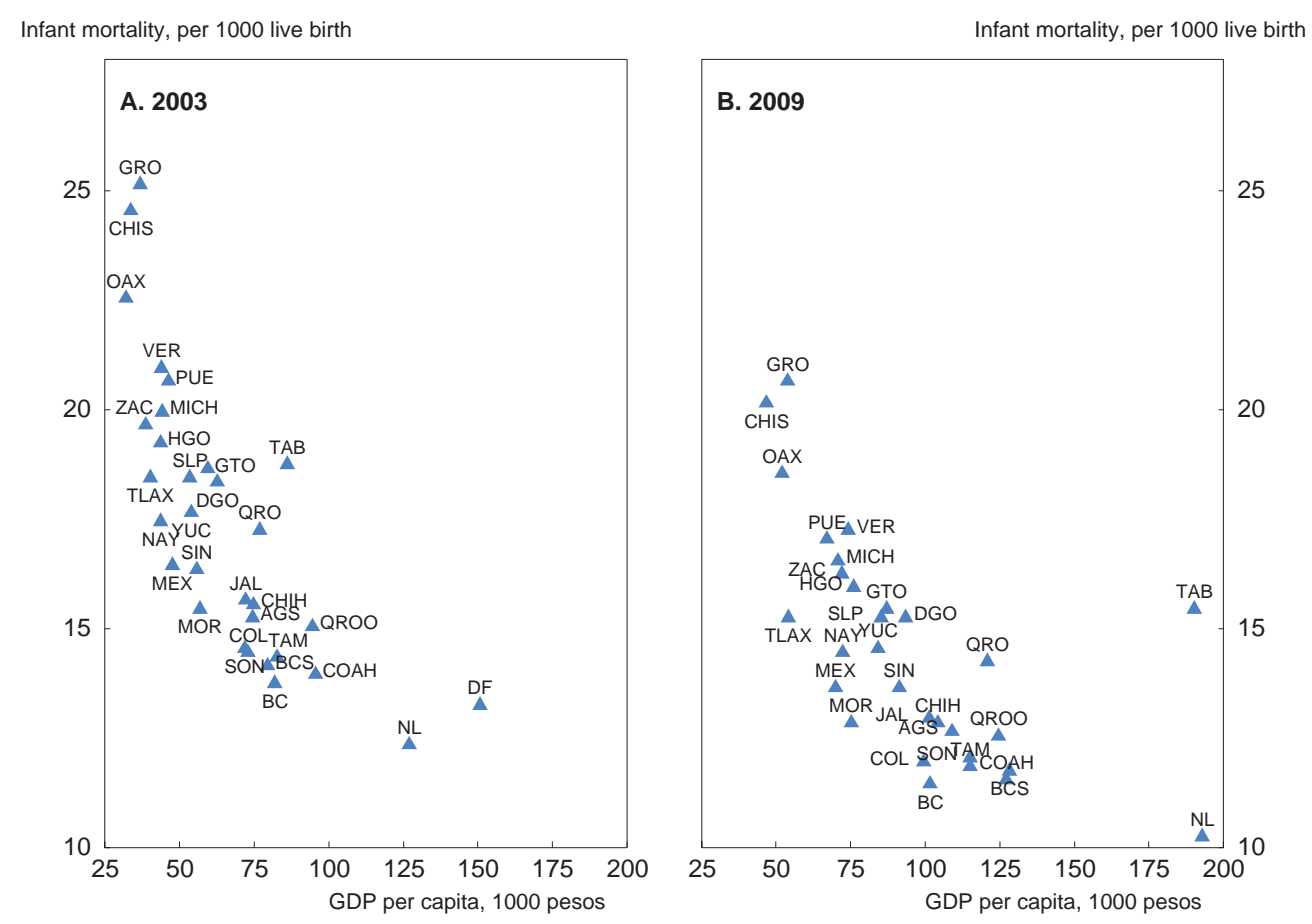

Source: Author analysis using data from INEGI. 
Figure 5. Health spending by state ${ }^{1}$
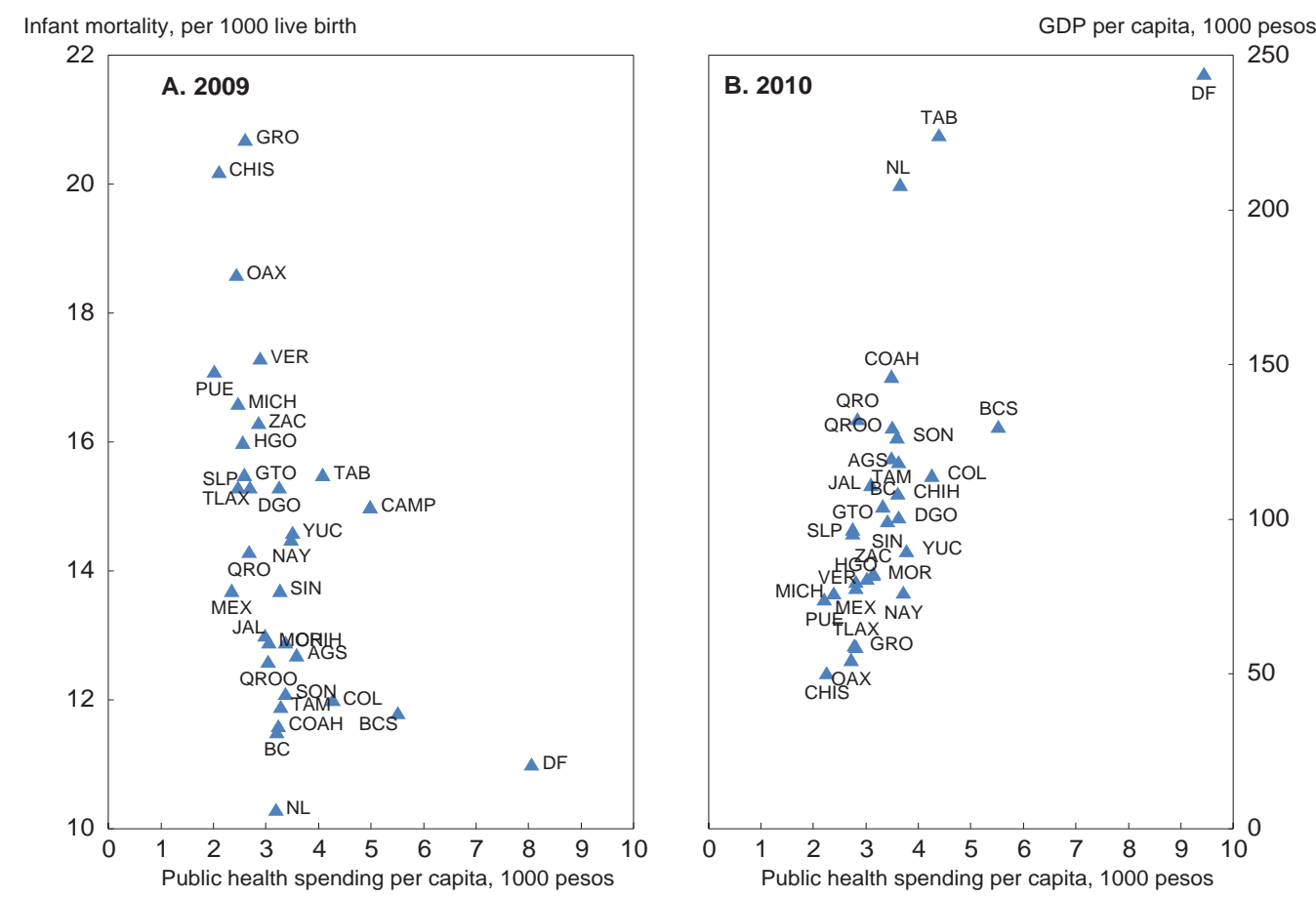

1. Health state spending for population with and without social security.

Source: Author analysis using data from INEGI and Secretaría de Salud.

A number of sources of inefficiency make the Mexican health system one of the least efficient in the OECD (Schwellnus, 2009). One key source is the fragmentation of health systems (social security institutes, private insurers, federal and state health services). Each system has its own vertically orientated provider with no access to each other services. This leads to costly duplication of health administration and infrastructure, reduces patient choice and competition between providers and leads to quality differences across providers. The decentralization of health has somewhat contributed to this fragmentation. While the primary purpose of decentralization was to reduce bureaucracy and improve coordination between federal and state providers for the uninsured population (Merino, 2003; Martínez-Fritscher and Rodríguez-Zamora, 2011), this has not been the case. Responsibilities overlap and there is a lack of coordination between federal and state levels. For example, the financing of hospital infrastructure at one level and the administration and maintenance of hospitals at another level (see Table 1) potentially results in underprovision and blame-shifting. States also lack autonomy because of the centrally negotiated labour contract for health employees that set wages and working conditions. This limits non-wage spending and reduces the productivity of professionals as there is no link to efficiency. Reducing overlapping and reforming paying mechanisms to reward high performance could contribute to improved efficiency in health care delivery.

Public spending that is more effectively targeted to health needs would reduce the differences in the quality of health care across regions. Despite reforms, public health financing per capita continues to be inversely correlated with indicators of need, such as infant mortality, as well as with GDP per capita (Figure 3.6). Regions finance the bulk of their health spending through an earmarked transfer (Fondo de Aportaciones para los Servicios de Salud, FASSA) allocated to states for the financing of health care for the non-insured population. Until 2004, the distribution of this federal transfer was largely based on historical costs of each state (adjusted for installed facilities and number of health professionals), rather 
than needs, with richer states often being much better-endowed than poorer states (Joumard, 2005). This contributed to the perpetuation of regional disparities in health care across the country.

The reform to the General Health Law in 2003 changed the formula with the aims of reducing the regressivity of the transfer and better linking resources to needs. The distribution of the transfer is now based mostly on the number of beneficiaries, with a small weight given to health needs, state health spending and a measure of spending efficiency (Annex Table A1.2). Since the change in the formula there has been a tighter correlation between FASSA and health needs (Figure 6). However, the small size of these improvements and the somewhat positive correlation between the allocation of the fund and GDP per capita suggests that there remains considerable space for making spending more equitable. The formula should be revised so that the allocation of resources becomes more transparent, gives greater weight to equity and promotes better incentives to states to provide better services. Increasing the transparency in the use of the earmarked health transfer would also contribute to better spending. Often there is no clear information on the allocation of funds at the state level (CONEVAL, 2011b). Furthermore, some evidence suggests that a non-negligible part of funding is used for other purposes than the financing of the health care for the non-insured population (Auditoría Superior de la Federación, 2009).

Figure 6. Earmarked health spending per state ${ }^{1}$
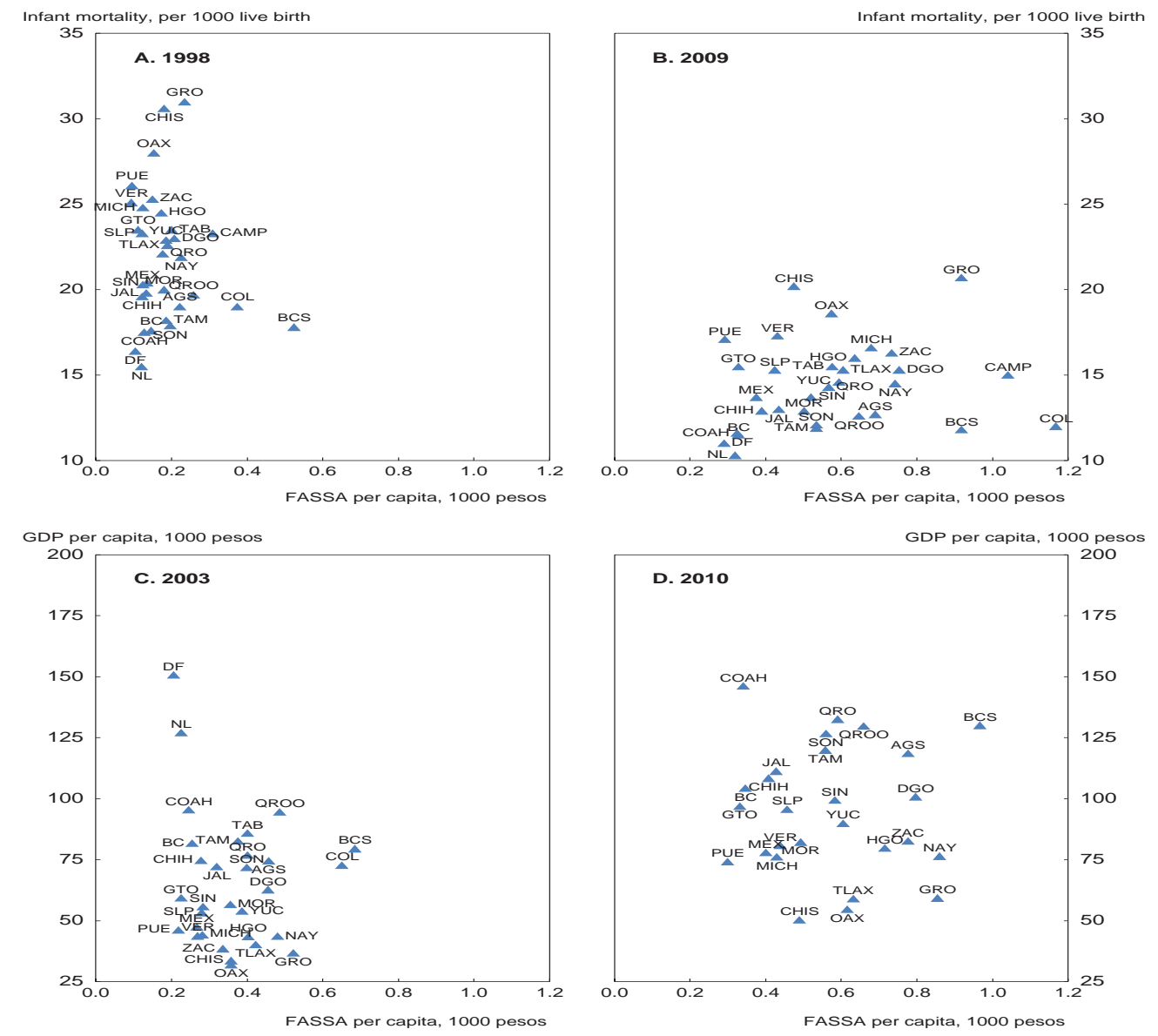

1. Fondo de Aportaciones para los Servicios de Salud (FASSA).

Source: Author analysis using data from INEGI and Secretaría de Salud. 


\section{Issues with intergovernmental revenue assignments}

\section{Sub-national tax autonomy is limited}

Mexican sub-national governments generate very limited own revenues relative to their expenditure responsibilities, leading to the largest fiscal gap among OECD countries (see Figure 3). Only 3\% of total states and municipalities' tax revenues stem from own taxes (those over which they have some discretion in setting the base and/or the rate), considerably lower than the average OECD country $(23 \%)$ and in particular than those with federal systems. This average also hides wide regional disparities, with some states, in particular the Federal District, raising a larger share of their own revenues (about 33\%, although this is partly explained by the fact that the Federal District collects both state and municipal taxes), almost double than the second state in terms of tax autonomy, Chihuahua (Castañeda and Pardinas, 2012). Heterogeneity is also wide across municipalities, but most of them have meagre resources and strongly depend on external financing (Figure 7) to finance basic infrastructure and public services.

Such low tax autonomy, which necessarily implies high reliance on transfers from the federal government, creates disincentives for sub-national governments to exploit their own revenue raising potential and build up their administrative capacities, given the political costs of own taxes and the resources needed to administer them. This leads to lower efficiency of spending, as there is no clear link between taxes and the benefits of public spending for which local politicians can be accountable, and possibly also reduces the incentives for growth promoting policies at the sub-national level.

Figure 7. Most municipalities depend on external funding

Distribution of own revenue in municipalities, 2008

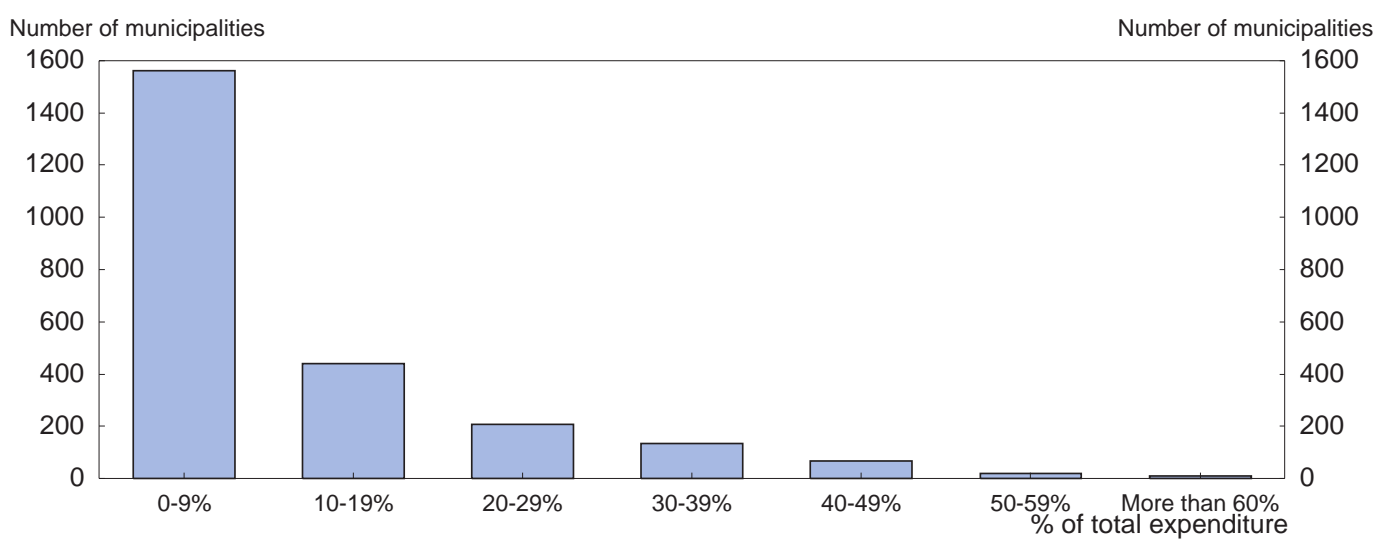

Source: IMCO using data from INEGI for the 2438 municipalities for which there is data.

The central government has made important and recurrent efforts to expand states' tax powers and increase their incentives to collect more own revenue. Past attempts included proposing to the states to levy a sales tax or a surcharge on income taxes, but states either refused, or have not used their new tax powers (González Anaya and Revilla, 2012). They argued limited capacity to levy these taxes. But a plausible additional reason was weak incentives, as it is easier for states to lobby for higher federal transfers than to step-up their tax raising efforts. Most recently, a reform in 2007 modified the system of intergovernmental fiscal relations (see Box 2). The reform increased incentives by discontinuing extraordinary transfers to states (OECD, 2011b). The formulas for various non-earmarked federal transfers were also reformed to include both the level and growth in sub-national government tax collection in an attempt to reward states' efforts to collect taxes. The reform also granted new taxes to the states. First, it allocated all the revenues from a newly created federal tax on diesel and gasoline to states. Second, it transferred the collection of taxes on vehicle ownership or use (tenencia) from the federal government to the states. And finally, it 
allowed states to levy a surcharge on goods subject to the federal excise tax (IEPS). However, few states have thus far used their new taxing powers. Besides, these new taxes have relatively limited revenueraising capacity and are not enough to close the gap between states' transfers and own revenues. For instance, less than half of states have introduced the vehicle tax. Following the reform, the share of own tax revenues in total sub-national revenue has only mildly increased from $10 \%$ in 2007 to $10.5 \%$ in 2009 .

\section{Reforms for additional revenue mobilisation at the sub-national level}

Further efforts are needed to expand sub-national governments own revenues. But before considering giving new tax powers to sub-national governments, the federal government should enforce a hard budget constraint on sub-national governments so they have the incentives to use their new tax powers. The federal government should limit further increases in transfers, so states and municipalities have more incentives to raise more of their own revenue. During the 2007 reform, while on the one hand extraordinary transfers were limited, states received a permanent top-up in their permanent transfers, by having access to fresh resources from the two newly created federal taxes (the IETU alternative minimum corporate tax and the withholding tax on cash deposits) through the revenue sharing agreement. So, overall all states received higher transfers in real terms as a result of the reform. This may have been necessary for the 2007 reform to go through (González Anaya and Revilla, 2012). But for future reforms to work, and truly mobilize sub-national governments' tax revenue, the federal government should refrain from giving more transfers to states and municipalities. The allocation of transfers should also not deviate from planned spending programmes and strictly follow the formulae in the allocation of transfers. Finally, extraordinary transfers should also continue to be avoided.

If the incentives can be improved, a second consideration for the federal government is: which new taxes to give sub-national governments? Answering that question first requires assessing the efficiency of the current sub-national tax mix, and whether such a mix could allow Mexican states and municipalities enough revenue to meet their expenditure responsibilities. Table A1.3 in the Annex summarises the main advantages and disadvantages of various possible sub-national tax assignments. From a normative point of view, the benefit principle of taxation would argue for sub-national governments to rely mainly on property taxes and user fees that provide a link between taxes paid and public services received (Oates and Schwab, 1988). Sub-national taxes should also ideally be levied on relatively non-mobile bases, where the base is relatively evenly distributed, to avoid tax erosion and strong disparities, as well as provide a stable yield (IMF, 1997; Joumard and Kongsrud, 2003).

For states, the most important source of own revenue is the payroll tax, accounting for almost $80 \%$ of states' revenue, a rare feature among OECD countries (Figure 8). Although relatively easy to collect, payroll taxes are not ideal, not least because they increase the cost of formal labour (Table A1.3, Annex). Another problem is that since payroll taxes are typically collected at the place where people work rather than where they live, if commuting between states is common, as for instance in the Mexico City metropolitan area that spans three states, revenues may flow to the state where core services are not provided. Other states' taxes include the tax on vehicle ownership, the lodging tax and the tax on lotteries. Although these are broadly appropriate for sub-nationals to handle, they have limited revenue raising potential and are arguably not enough to cover states' expenditure responsibilities in a sustainable way, if they are to deliver costly and important public services like education and health. 
Figure 8. State and local tax revenue

As per cent of total tax revenue, 2011

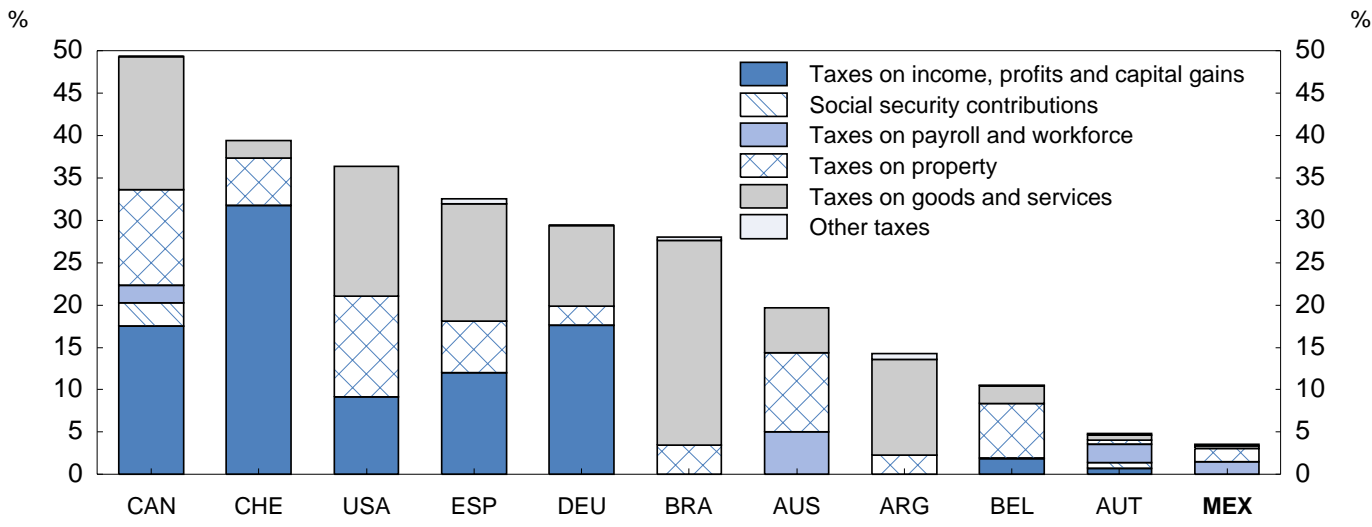

Note: 2010 for Argentina, Australia, Brazil and Mexico.

Source: OECD, Revenue Statistics database.

States should be given new powers over taxes with broader bases, such as a state income tax over and above the federal income tax or a consumption tax over and above the national VAT, where states would set rates. Experience among OECD federal states shows that, while in theory only a few taxes are best suited for subnational governments, in practice, a wide range of taxes are raised by them (e.g. Blöchliger and Petzold, 2009). For instance, about half of all taxes collected by OECD regions are taxes on income, profits and capital gains (see OECD Fiscal Decentralisation Database), and in half of all cases, regions have the power to set rates, as is the case in Canada or Switzerland. Therefore, although frictions can arise, overall they seem to have been manageable. Setting a federally defined maximum and minimum rate may be advisable to avoid horizontal competition and a race to the bottom. In the case of Mexico, a state income tax may be preferable to a consumption tax over and above VAT. The national VAT system is in need of reform, as it yields less than it could because of its big tax expenditures, zero rates and exemptions that substantially narrow the tax base (see Assessment and Recommendations). Allowing states to charge a consumption tax may add complexity to the VAT system and risk undermining any attempt of reform.

OECD experience suggests that it may be good practice to separate tax collection from tax setting. Thus income or VAT taxes set by lower levels of government can be collected at the federal level. Such an arrangement combines the advantages of local control over tax rates, and therefore higher accountability, with lower compliance costs for taxpayers and administration costs. For instance, much of Canada's extensively decentralised tax system operates in this way (Bird, 2011). Provincial personal income taxes are collected by the federal government in most provinces. In some provinces, provincial corporate income taxes and sales taxes are also collected by the federal government. But the provinces decide if they want to impose the tax, they also determine (within some limits or bands) its rates; and they receive all the revenues. Mexico could follow such example and while allowing states to set the tax rates, set the tax base at the federal level and let the federal tax administration (SAT) collect the tax on behalf of states for a fee.

\section{Municipalities should better exploit the property tax and water charges}

Municipalities derive the bulk of their tax revenues from property taxes (impuesto predial), a relatively easy to collect and efficient tax that involves few distortions. However, there is a large potential for increasing revenues, which are very low in international comparison, much below the OECD average and other Latin American countries (Figure 9). One problem is poor tax collection capacities. Some municipalities do not even have an official registry of the quantity, value and ownership of properties. In many others the update of such cadastres is infrequent, keeping the valuation of properties for tax purposes 
well below their market value. Evidence shows that cadastral values are $60 \%$ below market values in about half of the 32 states (Indetec, 2011). In part this is due to poor administrative capacities. The average Mexican municipality has low technical and administrative capacities, and a high rotation of municipal workers in charge of administering the property tax (Alvarez Estrada, 2009). Such high rotation is partly due to short terms of municipal office of three years and the no re-election law. Mayors in Mexico can only run for a single three year term and with each new election cycle the mayor must nominate new staff. What typically happens is that a complete new team of top and middle management public officials is appointed and most previous administrations do not leave any records behind (Smith, 2012).

Figure 9. Recurrent taxes on immovable property

As per cent of GDP, 2009

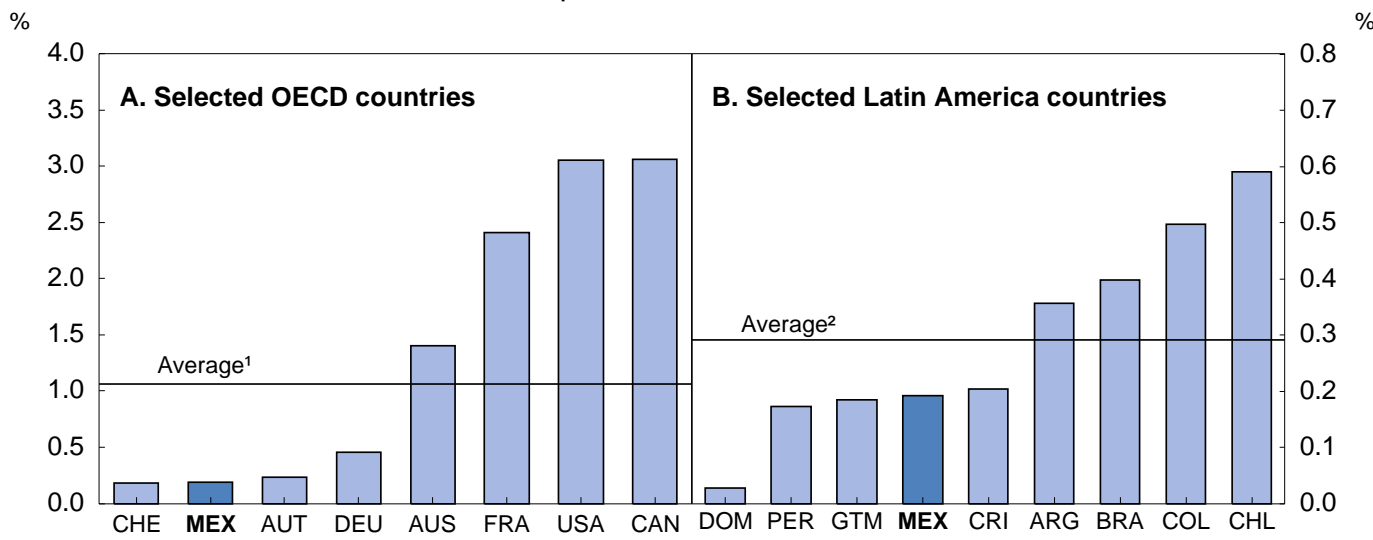

1. Average of all OECD countries.

2. Average of countries shown in the panel $B$.

Source: OECD Tax database; OECD Development Centre, Latin American Revenue Statistics.

Another major problem is weak incentives to collect higher property taxes. Empirical evidence on the relationship between federal transfers and local tax efforts in Mexico suggests that past increases in federal transfers have had a negative effect on local tax collection, in particular, property tax collection (Smith, 2012). Arguably given the choice, a local policymaker prefers to rely on federal transfers to finance public goods, instead of increasing local taxes, especially given that it entails a political cost. The non-consecutive three year term of mayors may also be too short to reap the benefits of taking the unpopular step to raise and collect property taxes. Exemptions are also common, with some municipalities giving property tax and water fees relief to some citizens on the basis of affordability concerns.

A first step for municipalities to strengthen their property tax collections would be to set up cadastres and carry out a comprehensive review of cadastral values to restore the tax base. For that municipalities could engage in state programmes to update land registries and strengthen their administrative capacities, as advised in the 2011 Economic Survey of Mexico (OECD, 2011b). States could hire and train the personnel and provide the infrastructure that is needed to update land registers, as already done with some success in the state of Puebla (González Anaya and Revilla, 2012). Another alternative is the new programme to update cadastres (Programa de Modernización Catastral) by the National Statistical Institute (INEGI) with the financial support of the development bank BANOBRAS, which has successfully contributed to updating the cadastre of 17 Municipalities and increased their property tax collection by an average of $40 \%$. For smaller municipalities, for which limited tax collection and technical capabilities are a key barrier for greater tax revenues, one alternative could be to agree with the federal or state tax administration, or with larger nearby municipalities to collect the tax on their behalf, for a fee. Municipalities should also ensure that cadastral values stay up-to-date. The reassessment of property values is obligatory by federal law since 1999, but it is hardly enforced. 
Increasing incentives to collect higher taxes will also be important. Extending the three-year term for mayors, or abolishing the non-re-election provision, would help in this respect. Chihuahua has recently lengthened the term for mayors to four years, which shows that change is feasible. Perhaps less politically sensitive and, thus, more feasible in the near term could be to take measures to reduce the frequent turnover among officials in municipal administrations that the non-re-election rule currently entails, by for instance appointing professional city managers to care for the day-to-day administrative operations of the municipality, as is the case in other OECD countries (e.g. Spain, United States). This could also contribute to much needed improvement in municipalities' technical and administrative capacities. A complementary alternative is to devise incentive mechanisms, such as special transfers to municipalities distributed partly on the basis of tax effort in collection of property taxes. Some states, including Nuevo León and Chihuahua, use such incentive schemes and now some of their cities (e.g. Chihuahua and Juárez) compare favourably in terms of own generated revenue (OECD, 2012c). Federal revenue sharing transfers to municipalities (Fondo de Fomento Municipal) are also allocated on the basis of municipal residential property tax and water fees collections since 2007. Mexico's overall property tax revenues per capita have slightly increased by 3\% in real terms between 2007 and 2009, according to government figures. In the longer term, it would, however, be advisable to reform the election rules for mayors so that citizens can reward or punish mayors and strengthen their incentives to make a more efficient use of public funds and provide good quality services to their citizens.

Revenues could also be enhanced by raising tax rates and eliminating exemptions Rates are relatively low by international standards, ranging from $0.05 \%$ to $1.2 \%$ of the cadastral value (Andrews et al., 2011). An important barrier municipalities face to increasing property tax rates is that they need state congress approval to do so, and state congresses typically do not want to bear the political cost of raising taxes. If municipalities could decide on tax rates, perhaps within limits set by the state, they could raise rates more easily and achieve greater revenue and spending flexibility.

Experience in other countries shows that higher property taxes are likely to be met with public resistance given their high visibility. To increase their public acceptance, tax increases following a reassessment should be done gradually. For instance, municipalities could envisage a transition period during which they set annual caps to individual increases in taxes. Special property tax relief arrangements to reduce affordability constraints for people with low incomes or illiquid assets could also be considered. These could include introducing a well-assessed and sufficiently high exemption threshold for low income households. Such a threshold would contribute to achieving a progressive profile and tax households with high housing wealth and income, which is important for a country with high inequality like Mexico.

Another pillar of municipal revenues is fees from the provision of water services. Despite their advantages compared to other possible sub-national tax sources (Annex Table A1.3), they generate very little revenue and are not sufficient to provide basic water services in a financially sustainable way. A key reason is that household water tariffs in Mexico are very low, the lowest among OECD counties (Figure 10). This national average hides wide variations across municipalities, but most tariff levels are generally not sufficient to cover the costs of providing the service (OECD, 2012e). Lack of cost recovery also hinders the private sector participation in water investments, despite the substantial investment needs in Mexico's water sector (OECD, 2012d). Low tariffs have also resulted in very high levels of water overexploitation in some water poor regions (OECD, 2012d).

There is also a widespread belief that low tariffs help the poor. But by preventing the development of reliable water supply low tariffs can hurt the poorest most, as they typically need to resort to private vendors, who charge much higher prices for water that is often unsafe. Targeted cash transfers are typically a more effective and less costly measure to address affordability concerns than lower water fees. 
Figure 10. Unit price of water and sanitation services to households including taxes 2008

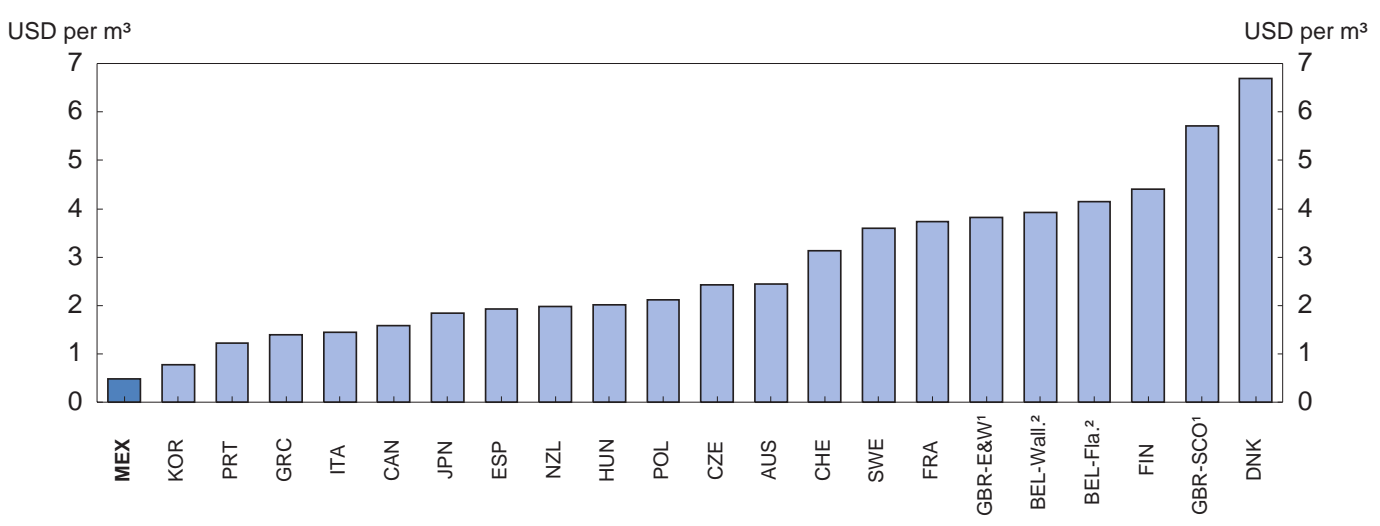

1. GBR-E\&W for England and Wales and GBR-SCOT for Scotland.

2. BEL-Wall for the Walloon region and BEL-Fla. for the Flemish region of Belgium.

Source: Pricing Water Resources and Water and Sanitation Services, OECD, 2010.

In 2012, the OECD carried out a policy dialogue with the National Water Commission of Mexico (CONAGUA) to assess the obstacles to implement Mexico's 2030 Water Agenda, which included a pillar on economic efficiency and financial sustainability (OECD, 2013b). A key conclusion from the dialogue was that to strengthen the financial sustainability of water utilities there is room for tariff increases in some places (OECD, 2012e). In most cases, however, a phased approach involving greater bill collection would be preferable to help put utility balance sheets on a firmer footing and build consumer trust and willingness to pay for higher tariffs. Currently, many beneficiaries, in particular public institutions, do not pay for their water services and this undermines private consumers' trust and willingness to pay. Another reason for low bill collections is illegal water connections. The sector also faces important water losses because of poor infrastructure maintenance (OECD, 2012e). As a result about $25 \%$ of water supply is currently not being paid for, according to CONAGUA estimates. Public authorities have a strong role to play to support greater bill recovery by ensuring that all bills are promptly paid. ${ }^{3}$

Political incentives to increase water tariffs will also need to be strengthened. Municipalities are typically in charge of setting tariffs, but their political leaders have limited incentives to increase tariffs and achieve sustainable cost recovery. As in the case of property taxes, the short-term mandate of mayors is a key factor limiting their incentives to raise tariffs. This added to the fact that federal subsidies for water provision are disconnected from municipalities' performance in providing water services makes it very unlikely that municipalities take the typically costly political step of raising tariffs. In fact, tariff increases generally only take place in those places where states are responsible for tariff regulation or where tariffs are adjusted automatically on a regular basis. Strengthening the role of the states, and in particular water commissions, in setting and revising water tariffs may therefore contribute to depoliticising tariff setting and ensuring a longer term approach to water provision and investment. This may nevertheless require working with state congresses and water commissions to raise awareness and build greater understanding

3. There are good practices in Mexico that have led to increased bill collection. For instance, CIAPACOV - a multi-municipal service provider in Colima - has increased commercial efficiency from $40 \%$ to $72 \%$ without social conflict thanks to a programme of "friendly bill collection" that combined making it possible to pay the water bill in newsstands, assigning different payment periods to different service areas and improving the quality of client services (see OECD (2013b) for more details). 
on the rationale and political economy of tariff setting, as well as to develop a more technical approach to water setting and regulation.

\section{Promoting better municipal spending for improved local public services}

While greater municipal revenue generation should help ensure adequate funding of municipal services, another important way of tackling emerging needs is by improving municipal spending efficiency. Municipalities are responsible for the financing of most basic infrastructure (e.g. water, electricity, local roads), where there are important investment needs (see Chapter 2). Moreover, many municipalities are small and have dispersed populations, which make financing challenging, because of higher costs of providing services.

OECD experience provides useful lessons for reducing costs and achieving economies of scale at the municipal level. Some countries, such as Denmark, have encouraged municipalities to merge (Blöchliger and Vammalle, 2012). However, mergers are politically cumbersome and efficiency gains usually come from organisational restructuring, which is typically difficult to achieve (OECD, 2006a). Cooperation agreements for the joint provision of services are often a better strategy (Joumard and Kongsrud, 2003). The joint provision of public services can create economies of scale and scope and thus offer possibilities to overcome scale-related production obstacles and to achieve cost-efficiencies. In Mexico, about a quarter of all municipalities already have formalised agreements with neighbouring municipalities for coordination and collaboration in the supply of such public services (OECD, 2012a). However, the annual nature of programme funding and the short-planning periods associated with the municipal election cycle limit cooperation (OECD, 2010b). Prolonging the election periods for mayors more in line with other Latin American countries, which have four to five-year terms, could help in this respect. Federal or state support may also be needed to establish successful collaboration agreements between municipalities (OECD, 2006a). Care should, however, be exercised so that there is not a proliferation in the number of cooperation entities without a clear substitution of the services provided by municipalities leading to a wasteful duplication of resources, as has been the case, for instance, in France (Cour des Comptes, 2009).

The development and use of performance indicator systems can also contribute to promoting capacity building, and improving municipal spending efficiency through competition and learning among municipalities (OECD, 2006a). Norway's KOSTRA system (see Box 3), for example, has brought several benefits to Norwegian municipalities. First, and foremost, it has provided municipalities with a tool for internal planning, budgeting, and benchmarking (OECD, 2010c). But it has also helped the central government to assess if municipalities are complying with national standards and regulations and their needs for federal funding. For Mexico, with three times more municipalities than Norway, establishing a similar measurement framework would be challenging, but not impossible. Municipal information is already gathered, standardised and published for over one hundred municipalities by the national statistical agency (INEGI). Mexico could build on these efforts to develop a performance indicator system inspired by Norway's and reap the benefits of benchmarking through improved spending, greater accountability and transparency. 


\section{Box 3. The Norwegian KOSTRA system: ${ }^{1}$ what gets measured gets done $\&$ improved}

Norway's KOSTRA system is a pioneer of information sharing among local governments (OECD, 2012b, 2010c). It gives individual municipalities' access to budget information from other municipalities for the purpose of comparison. Information includes how much money municipalities spend, how they spend it as well as other variables that allow assessing the efficiency of municipal spending. The data is managed by Statistics Norway and reporting to KOSTRA is mandatory for all Norwegian municipalities, therefore the coverage of the data is broad, although improving data reliability is always an on-going effort. Key standardised indicators are published on the internet, so municipalities can easily access them to benchmark their performance against average comparable municipalities. Academics can also access the data and conduct useful research assessing policy effectiveness. The ten largest municipalities also participate in a system called ASSS-Teamwork where members meet regularly, using KOSTRA and other data, to compare their performance.

1. More information and data from the KOSTRA system can be found on the Central Bureau of Statistics of Norway's homepage: www.ssb.no/english/subjects/00/00/20/kostra_en/.

\section{Sub-national governments depend on a complex system of federal transfers to finance their spending}

The system of intergovernmental transfers combines revenue sharing (non-earmarked) transfers (participaciones), a myriad of earmarked transfers (aportaciones), and some matching transfers (convenios). The bulk of transfers are channelled through 16 different funds to states and municipalities with very different and sometimes opaque or hard to measure allocation criteria. Tables A1.1 and A1.2 in the Annex present the main transfers, its distribution criteria and their weight in the federal budget. Such complexity, combined with sparse information on the use of federal transfers, makes for a system that is liable to poor public accountability and has great scope for rent-seeking. Although hard to quantify, administration costs must also be high, given the large number of funds and the lengthy negotiation process between the federal government and states for the allocation of most funds.

In addition, the overall distribution of transfers is not particularly equalising (Figure 11, Panel A). Also there is little relationship between tax effort and transfers per capita across states (Figure 11, Panel B). 
ECO/WKP(2013)70

Figure 11. Transfers are not equalising and little related to local tax effort ${ }^{1}$ 2010
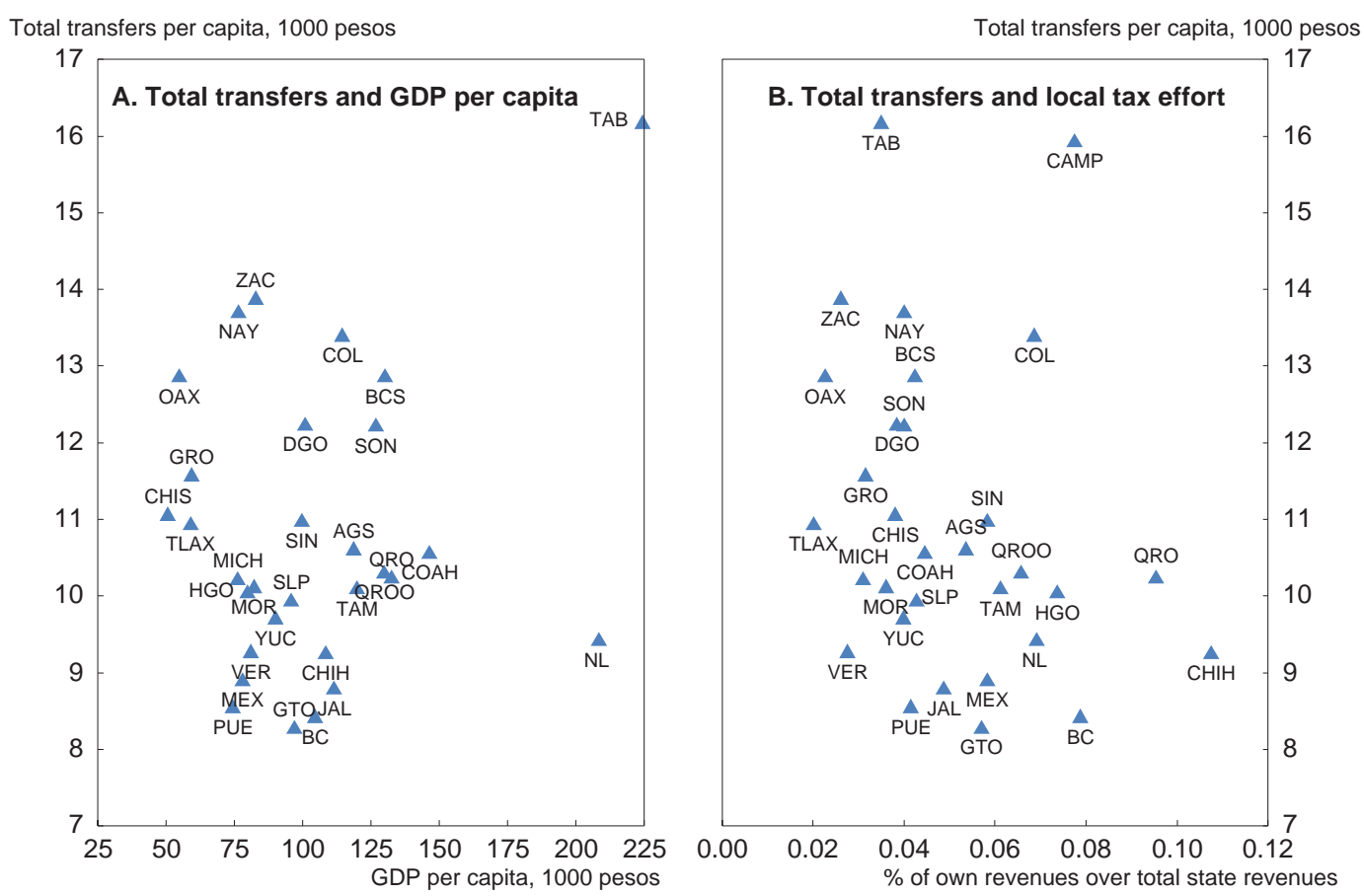

1. Total transfers include earmarked transfers (aportaciones) and non-earmarked transfers (participaciones), accounting for over $90 \%$ of all transfers from the federal government to states. Own revenues include taxes and fees. No data available for Distrito Federal.

Source: Author analysis using data from INEGI, Sistema Estatal y Municipal de Base de Datos.

\section{Revenue sharing}

Revenue sharing is the most important source of federal transfers $3.7 \%$ of GDP and $40 \%$ of subnational revenue). The central government collects the most important taxes, including income taxes, VAT and revenues from oil and mines, and shares them with states and municipalities by means of nonearmarked transfers channelled through various funds (Annex Table A1.1).

The distribution of revenue sharing transfers was originally designed to compensate states for relinquishing their taxing powers. As a result, for a long time richer and oil-producing states received more than poorer ones contributing to deepening rather than reducing regional disparities (Joumard, 2005). The allocation formula of the largest fund (Fondo General de Participaciones), which accounts for almost 90\% of non-earmarked transfers, also gave perverse incentives. It allocated transfers mostly on per capita basis, but also on the growth of federally coordinated excise taxes collected by states. The idea was to use excise tax collections as a proxy for local economic activity and tax revenue, and encourage state economic growth. It encouraged instead greater consumption of alcohol, tobacco and gasoline, thus potentially increasing states' health cost burden (González Anaya and Revilla, 2012).

The 2007 fiscal reform changed the allocation formula of the largest fund to make it simpler and improve the incentives embedded in it (see Box 2). The new formula allocates transfers on the basis of states' GDP growth and local tax collection efforts (Annex Table A1.1), and seeks thereby to strengthen sub-national governments' incentives to increase local tax effort and foster local economic activity. This change is welcome. The allocation of non-earmarked transfers does not yet seem to follow the new criteria but rather pre-reform allocations, possibly because the hold-harmless clause included in the new formula 
implies a long transition period (see Box 2). But over time the new formula should contribute to promote states' economic growth and tax autonomy, and thus help to reduce states' dependency on federal transfers.

One drawback of allocating transfers on the basis of local tax efforts and economic growth, though, is that funds will go to richer over poorer regions and thus contribute to keep deepening regional disparities. Therefore other features of the system will need to be reformed to achieve greater equalisation, as discussed below.

\section{Earmarked transfers}

Earmarked transfers - channelled through the Ramo 33 (see Table 1) - are the second most important source of transfers (3.6\% of GDP and 38\% of sub-national revenue). The largest funds, accounting for $60 \%$ and $12 \%$ of all earmarked funds respectively, are earmarked to education and health. They were designed to finance the spending responsibilities transferred to sub-national governments in the decentralisation process. Despite reforms, the allocation of these funds is not yet correlated to needs and the transition may take a long time. In addition, allocation is based on formulae for which either reliable information does not exist for many states, like health and education spending, or for which there is no clear definition, like education quality and health spending efficiency. The allocation of these funds should be reformed along the lines discussed above, so that is more closely related to need and quality of spending. More efforts need also to be made to assess the use of earmarked transfers based on outcomes.

The remaining earmarked funds have mostly an equalisation purpose seeking to improve services in the poorest states and municipalities. For instance, the Social Infrastructure Fund (FAIS) is one of the largest among those funds. It seeks to address infrastructure gaps in an effort to reduce poverty and promote regional development and finances basic infrastructure projects in municipalities, such as potable water, sewers, drainage, urbanisation etc (Salazar Domínguez, 2011). The fund does seem to be allocated according to needs. States with a higher degree of marginalisation, such as Chiapas or Oaxaca, do indeed receive more resources from this fund (Figure 12). A possible drawback though is that its distribution does not take into account regional externalities. Most of its resources (about 90\%) are allocated on a municipality by municipality basis. While in principle it is highly desirable that the provision of municipal goods and services is administered at the local level, where needs are, many of these goods have regional externalities and would be more suitably managed at the state level. 
Figure 12. The social infrastructure fund does target marginalisation ${ }^{1}$

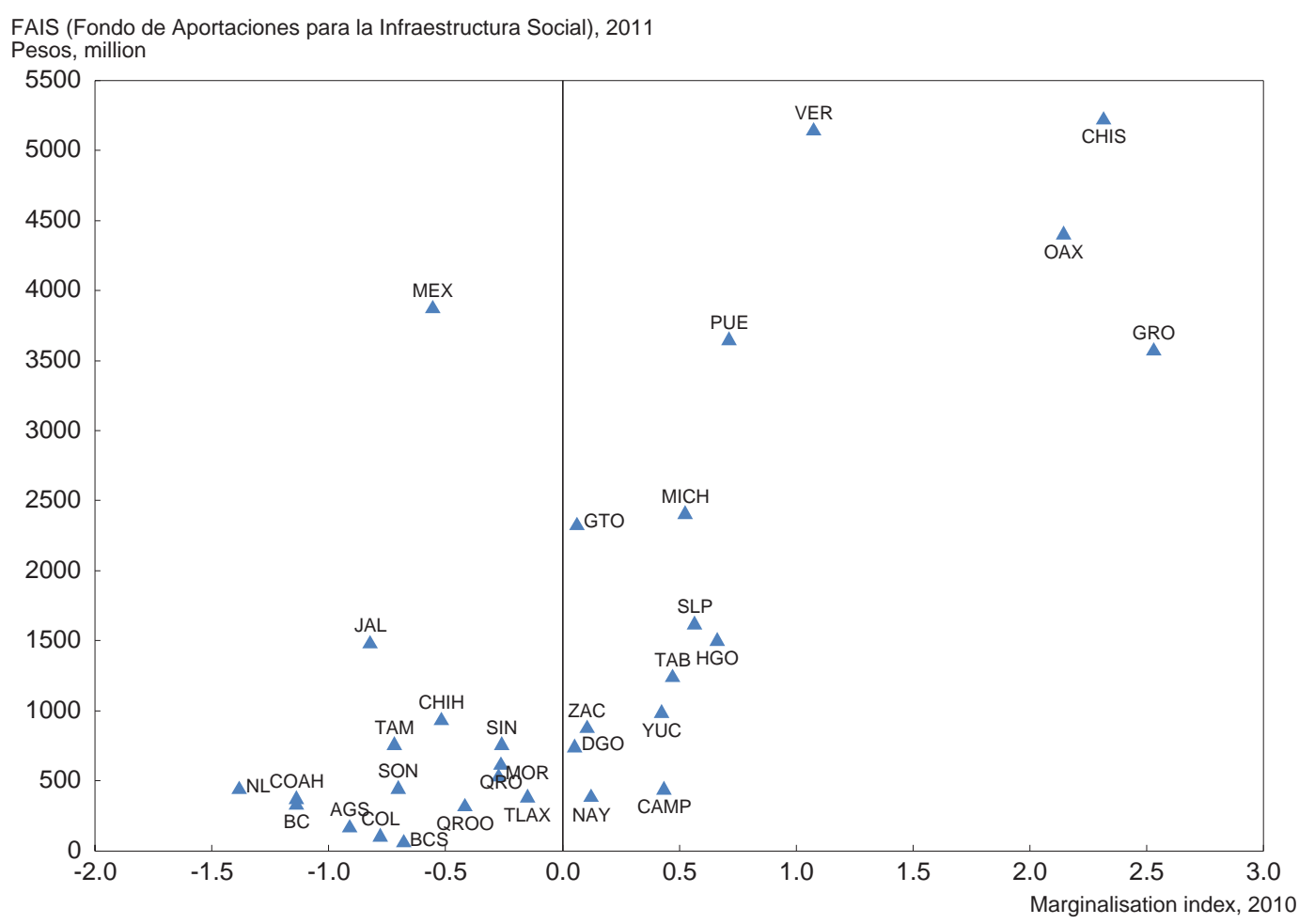

1. No data for Distrito Federal.

Source: Author analysis using data from CONAPO and Sedesol.

\section{Other transfers}

Sub-central governments also receive some, albeit small (about $6 \%$ of total sub-national revenues), resources from individual federal ministries and agencies through matching transfers (convenios de descentralización). Their advantage compared to other transfers is that they are subject to tighter federal supervision and auditing controls. However, as they don't follow any formula they lack transparency in their allocation.

Another area where the allocation criteria are not clearly defined is in the transfer of federal funds from states to municipalities. For instance, states are required to allocate at least $20 \%$ of the revenuesharing transfers they receive from the federal government to municipalities. However, there is no uniform or clear distribution formula across states and this can similarly lead to rent-seeking and corruption. It also leads to unpredictable levels of annual financing for municipalities complicating their planning and budgeting for public services. Clear formulae should be used to allocate these funds. As regards municipalities, clearer and transparent allocation criteria combined with a municipal performance measurement system, as discussed above, could contribute to increased accountability in the municipal use of transfers.

\section{Improving the equity of the transfer system}

One of the most important challenges that Mexico faces is the large inequality levels in the country. Mexico has made remarkable progress in reducing poverty and inequality over the past fifteen years. However, poverty and inequality remain high by international comparison, not only relative to OECD countries, but also relative to other emerging economies. Mexico's regional disparities are also among the 
top in the OECD. Differences in sub-central GDP per capita, are the largest among OECD countries and have increased over time (Figure 13). Mexico should strengthen its social policies to fight poverty even more aggressively, as argued in the Assessment and Recommendations, but it should also strengthen the equity of its transfers system so Mexican citizens have access to an acceptable degree of public services regardless of their region of residence. If schools or health services in poor regions are of poor quality, cash transfers to the poor cannot be very effective in reducing poverty.

The Mexican transfer system, while it does not have an explicit equalisation framework, does embed some equalisation features within its earmarked transfer system, as described above. However, the system is not very effective in reducing Mexico's large disparities. Moreover, increasing sub-national governments' tax autonomy, as recommended above, may deepen fiscal disparities as other things equal, richer states and municipalities will collect higher tax revenues (Blöchliger and Petzold, 2009). Greater fiscal equalisation could also bring efficiency gains by avoiding regional differences becoming selfperpetuating and by setting the basis for effective fiscal competition (Joumard and Kongsrud, 2003).

Figure 13. Regional disparities across OECD countries

Regional disparity (Gini index of GDP per capita)

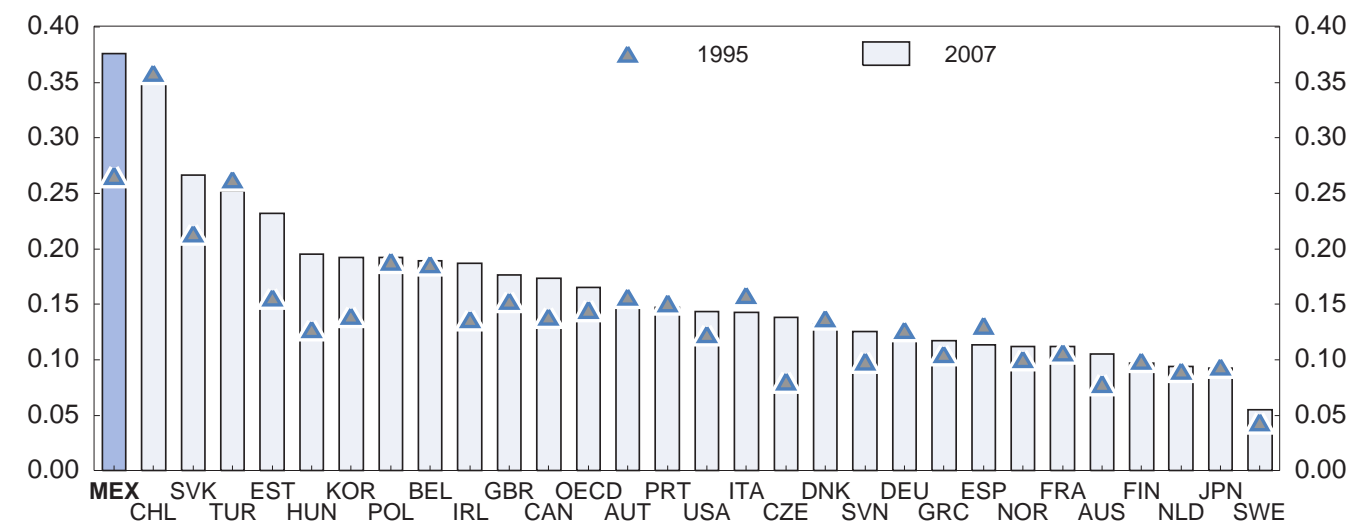

Source: OECD (2009) Regions at a Glance, OECD Publishing, Paris.

While all OECD federal countries, except the United States, have some sort of equalisation system OECD experience suggests that designing a well-functioning system is not an easy task and great caution is needed (Blöchlinger et al., 2007). There is no one-size-fits-all solution: fiscal equalisation systems are very country and history specific. And often there are some efficiency-equity trade-offs that need to be considered. For instance, equalisation transfers can reduce tax and development effort in poorer regions and create poverty traps by reducing sub-national government incentives to introduce growth-promoting policies (Joumard and Kongsrud, 2003). They can also pose a problem for budget stability in particular if transfers are open-ended and/or if local governments are entitled to a minimum fiscal capacity.

A first option for Mexico to improve the equalisation properties of its system could be to reform some of its revenue sharing transfers so they follow simple and more equalising criterion, such as population or income per capita. However, based on OECD experience it is better to separate redistribution from tax raising incentives, which the current revenue sharing formula seeks, for the sake of transparency and simplicity (Blöchliger et al., 2007). Reforming the current revenue sharing system may also be politically difficult, given that it was recently reformed and this required substantial negotiation. Frequent formula changing is also not advisable as it can complicate sub-central governments' budget planning.

Instead, Mexico could consider a new system of unconditional federal transfers to the most deprived areas (as in Canada), or directly from richer to poorer regions (as in Germany) organised on a cooperative 
basis. Both options have the advantage that redistribution is clear and transparent. In principle redistribution from richer to poorer states could be preferable as it has the advantage of increasing accountability and reducing incentives for free riding, as donor states would have incentives to check more closely how receiving states are using their money. It also favours fiscal stability as it doesn't draw resources from the federal budget. Redistribution from richer to poorer states may, however, be more politically difficult to achieve as it can lead to strong opposition to transfers from the better-off states. In such a case, equalisation from the federal government may be politically easier.

Key issues, in either case, are that transfers are based on clear distribution rules and on simple and hard to influence criteria, such as for instance GDP per capita, and that marginal equalisation tax rates are not excessively high. A too high equalisation tax (the rate at which additional own tax revenue is equalised away) can reduce a jurisdiction's effort to develop its economic and fiscal base and can also slow down regional convergence within a country (Blöchliger et al., 2007).

\section{Measures to reduce the pro-cyclicality in sub-national revenues}

It is important that sub-national governments' total pool of available resources is flexible enough to meet changing budgetary needs, but also predictable enough to ensure an efficient allocation of resources. In Mexico, however, sub-national government revenues are highly volatile and this is in part because of transfer system, which exacerbates states' revenue fluctuations and does nothing to attenuate GDP fluctuations (Box 4). Most transfers are set as a fixed percentage of the revenue sharing pool, and thus as a fixed percentage of the federal government tax and oil revenues, which are highly cyclical. Revenue volatility can have efficiency costs and impair long-term growth by leading to sharp fluctuations in public expenditure. It can also have social and political costs if leads to sharp retrenchments in socially sensitive sub-national spending programmes during cyclical downturns, as shown by countries strongly affected by the recent global financial crisis.

\section{Box 4. An assessment of the stabilisation properties of the Mexican intergovernmental transfer system}

The stabilisation properties of intergovernmental transfers can be assessed using a variety of indicators. The simplest and crudest approach is the correlation between fluctuations in sub-central governments' tax and transfer revenues, where a negative correlation indicates stabilisation, while a positive correlation points at a destabilising transfer system. For Mexico, such correlation coefficient equals 0.38 over the period 1989-2010, indicating a destabilising effect of transfers.

A more reliable way is to follow the methodology developed by von Hagen and Heppe (2001) and regress the annual fluctuations in transfers on GDP and sub-central government effort. This simple bivariate analysis, while it does not control for all the determinants of transfers because of the lack of available data, can shed light on the extent to which the intergovernmental transfer system acts as a buffer against regional income shocks and against fluctuations in local government tax collections. The size and the sign of the coefficients will then indicate whether transfers follow the cycle and/or variations in local tax revenues, or by contrast are destabilising. The estimated regression equation is

$$
\frac{x_{i t}-x_{i t-1}}{y_{i t-1}}=\alpha_{t}+s_{i}+\beta \frac{y_{i t}-y_{i t-1}}{y_{i t-1}}+\varepsilon_{i t}
$$

Where $i$ denotes state and $t$ denotes year, $x_{i}$ stands for the transfers state $i$ receives from the federal government in year $t$ and $y_{i t}$ stands for GDP in state $i$ at year $t$, or state $i$ local tax revenues in year $t$, depending on the regression, $\alpha_{t}$ are year fixed effects, and $s_{i}$ are state fixed effects. The coefficient $\beta$ measures the extent to which transfers provide an insurance against asymmetric region-specific GDP shocks or shocks to local tax revenues, depending on the regression. A $\beta=-1$ indicates the transfer system provides complete insurance against shocks. $\mathrm{A}$ $-1<\beta<0$ indicates transfers partially stabilise GDP fluctuations, or fluctuations in states' tax revenues, thus have a stabilising component. A $\beta>0$ indicates that transfers are pro-cyclical, in the case of GDP, or destabilising, in the case of local tax revenues. The following table presents the results for the Mexican transfer system employing annual data for Mexican states from 1989 to 2010.

\begin{tabular}{|c|c|c|c|c|c|c|c|c|}
\hline Variables & (1) & $(2)$ & (3) & (4) & (5) & $(6)$ & (7) & (8) \\
\hline GDP growth & $0.196^{* *}$ & & 0.0583 & & $0.232^{* *}$ & & 0.120 & \\
\hline
\end{tabular}




\begin{tabular}{|c|c|c|c|c|c|c|c|c|}
\hline & $(0.0964)$ & & $(0.119)$ & & $(0.0914)$ & & $(0.106)$ & \\
\hline \multirow[t]{2}{*}{ Own tax revenue growth } & & $0.0849^{* * *}$ & & $0.0632^{* * *}$ & & $0.0709^{* * *}$ & & $0.0414^{* \star *}$ \\
\hline & & $(0.0111)$ & & $(0.0125)$ & & $(0.0106)$ & & $(0.0117)$ \\
\hline \multirow[t]{2}{*}{ Constant } & $9.250^{* * *}$ & $4.213^{* * *}$ & $8.919^{* * *}$ & $12.06^{\star * *}$ & $6.280^{*}$ & $5.365^{\star * *}$ & $5.408^{*}$ & $14.53^{\star * *}$ \\
\hline & $(1.050)$ & $(0.507)$ & $(2.130)$ & $(1.979)$ & $(3.275)$ & $(2.056)$ & $(2.921)$ & $(2.571)$ \\
\hline Year fixed effects & No & No & Yes & Yes & No & No & Yes & Yes \\
\hline State fixed effects & No & No & No & No & Yes & Yes & Yes & Yes \\
\hline Observations & 217 & 651 & 217 & 651 & 217 & 651 & 217 & 651 \\
\hline R-squared & 0.019 & 0.083 & 0.365 & 0.218 & 0.299 & 0.237 & 0.642 & 0.380 \\
\hline
\end{tabular}

Notes: Standard errors in parentheses. ${ }^{* * *} p<0.01,{ }^{* *} p<0.05,{ }^{*} p<0.1$

Focusing on the preferred set of results, including state and year fixed effects, the results suggests the system provides no insurance against asymmetric GDP shocks and is even destabilising in the case of own tax revenue. In particular, a non-significant $\beta$ coefficient in column 7 suggests the transfer system does not ensure states against fluctuations in states' GDP. A positive and significant $\beta$ coefficient in column 8 suggests the transfer system has a destabilising effect relative to tax collections. While the simplicity of this approach, may warrant some caution in interpreting the results, more sophisticated analysis by Blöchliger and Egert (2013) controlling for a large number of determinants of transfers and for endogeneity of the business cycle using a GMM approach confirms that in Mexico transfers do not ensure against fluctuations in GDP.

There are a number of measures countries can use to reduce the pro-cyclical features of intergovernmental transfer systems and strengthen their automatic stabilisation properties (Blöchliger and Petzold, 2009; Ter-Minassian and Jiménez, 2011). One option for Mexico is to limit the weight of cyclical and oil price developments in the formula. This would reduce the scope for transferring volatility from federal to state finances. It would also help to avoid temporary increases in federal transfers being transmitted into permanent increases in sub-national spending.

Another option is to build some countercyclical features or smoothing mechanism in the sharing formula. Such as for instance using lagged or moving averages of national revenues as a base of sharing, that would allow for longer periods to adjust fluctuations in national revenues. Though such a system could lack the necessary flexibility in reacting to legitimate sub-central needs, using lagged or moving averages variables could reduce excessive revenue volatility.

\section{Improving public financial management}

A clear and transparent public financial management framework at the sub-national level is a key ingredient for effective fiscal decentralisation and public management (Fedelino and Ter-Minassian, 2010). It facilitates consistent decision-making to ensure macroeconomic stability and accountability for an effective use of public money. A package of measures in public financial management could help to improve budgetary practices, transparency and promote good governance in Mexico.

\section{Budgetary practices}

States lack flexibility in the use of their budgets, as most of their resources are either earmarked to health and education, or are allocated to administrative and operational spending. This coupled with the fact that states' budgets have an annual term, with no possibility of authorising longer term budgets that could allow a longer and more strategic financial planning horizon to enhance their economic opportunities, makes for very inflexible budgetary practices. Introducing multiyear sub-national budgets would provide more certainty and help to integrate multiyear programmes and medium-term objectives into their budgetary planning. More broadly Mexico as a whole will need to develop a longer-term budget focus that aligns spending and funding with the government's plans and goals for different sectors, and 
prepare better for eventualities such as declining oil revenues and population ageing (see the Assessment and Recommendations).

\section{Coordination}

Although Mexico is a federal country, policy decisions remain quite centralised. Sectoral policies, as for instance in education and health, are largely designed at the federal level, but implemented at the state and local level. In the absence of effective coordination mechanisms between different levels of government, policy making at the regional and local level in Mexico is highly fragmented, making it hard to design strategies and policies tailored to local needs (OECD, 2012f). For instance, no coordination system exists for public spending across states that allows coordinating priorities and decisions on spending. This can lead to weakened public financial management and a lack of consistency with national macroeconomic objectives (IMF, 1997).

Better coordination between the federal and state governments could be pursued through the creation of institutions bringing together states' policymakers and national policymakers and fostering joint responsibilities for fiscal and development plans. Several good examples of such coordinating institutions exist across OECD countries. One example is the intergovernmental forum in Australia (Council of Australian Governments, COAG). The COAG is in charge of initiating, developing and implementing reforms of national importance that require cooperative actions by Australian states. Its reform council monitors the implementation of reforms decided by the COAG and has successfully contributed to the implementation of the regulatory reform agenda across Australian states (OECD, 2010e). Another good example is the Stability Council in Germany, which is in charge of coordinating the budgets and financial plans of the different levels of government (Deutsche Bank, 2011). In Mexico the State Governors' National Conference (Conferencia Nacional de Gobernadores, CONAGO) could perhaps play such coordinating role. While this may require strengthening the CONAGO's technical capacity and expanding its rather political mandate, it may be worthwhile pursuing given that the CONAGO is already the main interlocutor of the federal government when it comes to issues regarding the states.

\section{Transparency}

A necessary condition to evaluate efficiency in public spending is the availability of transparent and accurate information on spending. However, until very recently in Mexico, there was no homogenous and agreed upon standard method for accounting and reporting of revenues, spending and debt of sub-national entities. As a result, official documents are not clear, have missing information on salaries, number of state employees and debt, as well as how much revenue is transferred to municipalities. This complicates the comparison of resources available to subnational governments, as well as the evaluation of their fiscal performance. It also leads to lack of transparency and possibly corruption. A recently-adopted Law on Government Accounting should enhance the transparency of subnational finances. The law introduces a common template for reporting financial and budgetary information - including revenues, expenditures, debt and financing sources - at the state and municipal levels, which will have to be published on a quarterly basis.

The new law represents a great advancement. However, the federal government should ensure that it is fully implemented. In 2008, Congress granted authority to the federal legislature to enact laws governing accounting practices for all levels of government and accrual accounting (Governmental Accounting General Law), thereby establishing the legal basis for uniform national accounting by 2012 for states and 2013 for municipalities. However, few entities adopted the rules. This time the stiff penalties for government officials not applying the law, including prison, may foster implementation. But implementation will require extensive capacity-building in many jurisdictions, in particular municipalities, and may therefore require considerable support from the federal government to ensure its enforcement. 


\section{Subnational governments' debt has been increasing and pension liabilities are large}

Subnational government debt, although remains low by international standards, and therefore is not a systemic risk, has almost doubled - from 1.6\% to 2.8\% of states' GDP - between 2007 and 2012 (Figure 14). ${ }^{4}$ Some evidence also suggests that spending is higher than revenues in several states and municipalities and current liabilities have reached unsustainable short term levels, increasing the risk of refinancing (Fitch, 2011b). In 2012, one state and several municipalities have not been able to pay their debt and required refinancing. Comparing states' liabilities to own revenue, a better measure of financial sustainability, suggests that, by this account, states are the worst performers in the OECD (Figure 15).

Figure 14. Sub-central government debt, 2009

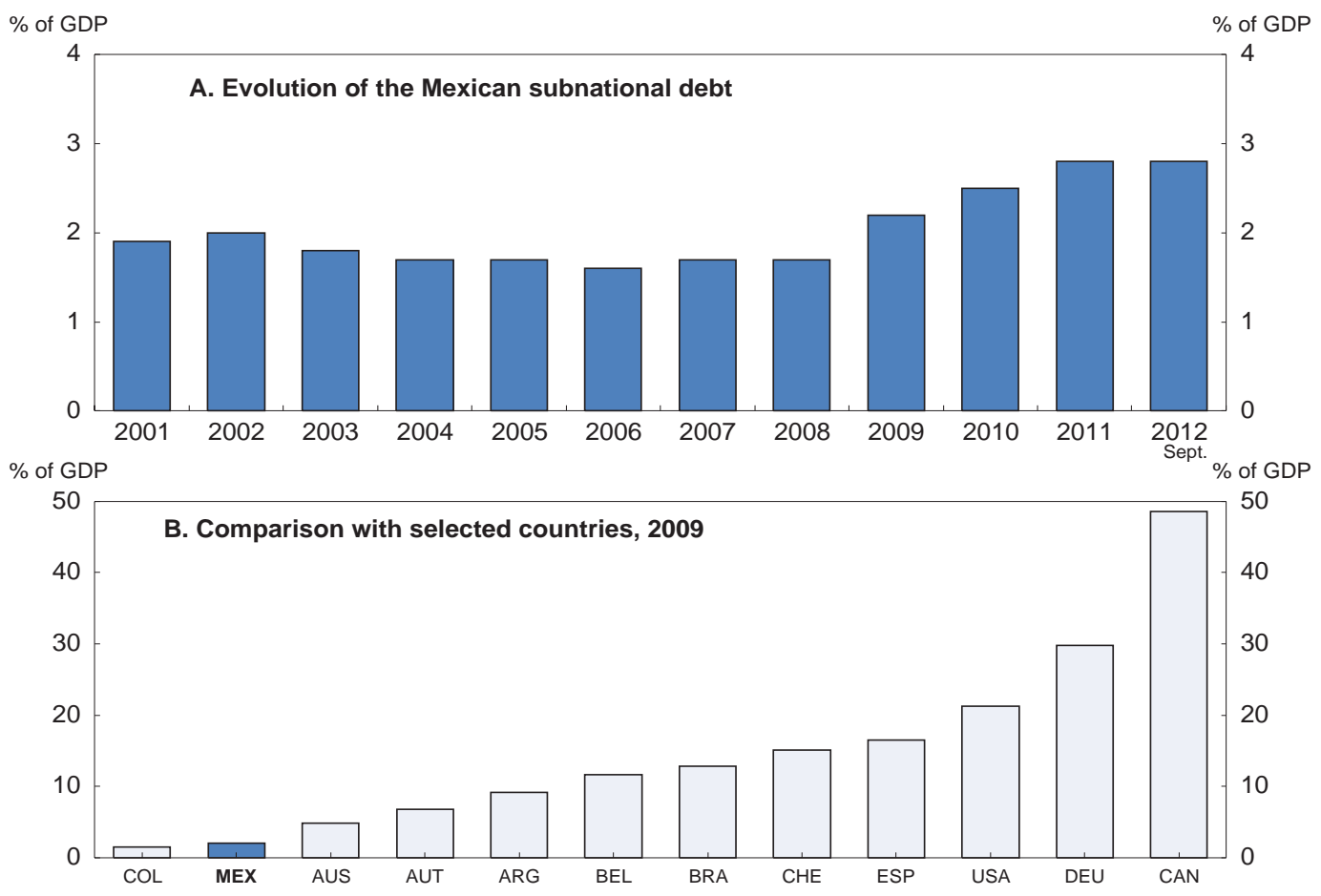

Source: Registro SHCP; OECD, Economic Outlook database; Interamerican Development Bank.

4. This debt includes all liabilities that are incurred by subnationals which are registered with the Federal Ministry of Finance, and that were approved by their local legislatures. It does not include short-term loans, or contingent liabilities such as pensions or suppliers' credit. 
Figure 15. Fiscal gaps ${ }^{1}$

As per cent of sub-central tax revenues

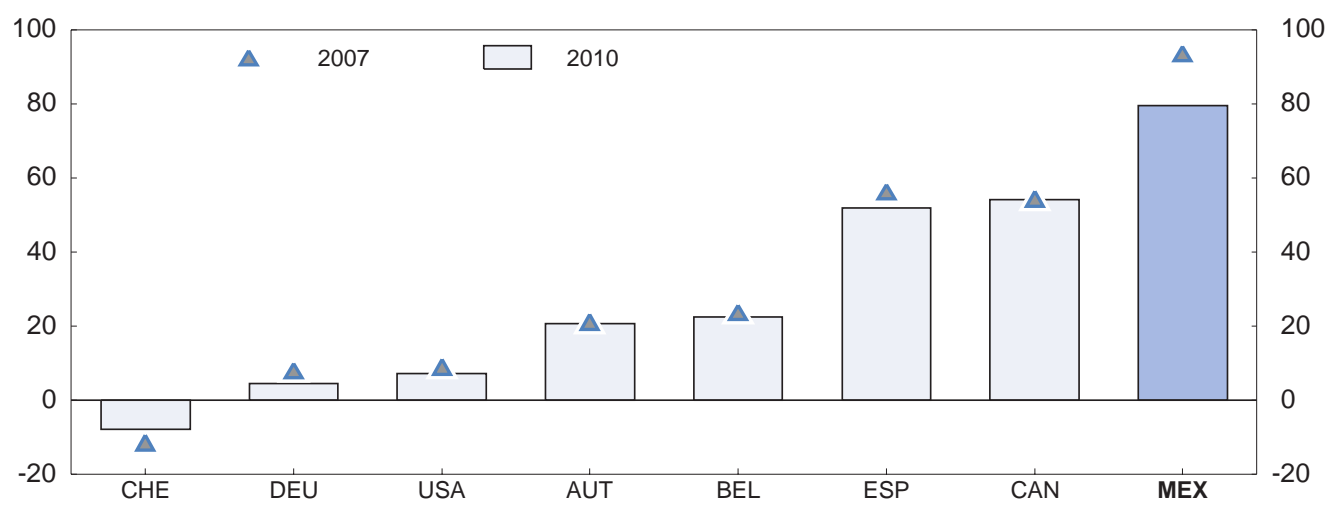

1. Actual fiscal gaps are defined as the additional and permanent improvement - above outcomes in 2009 - in primary balances required to hit the debt-to-GDP ratios of 2007 or 2010 in 2026. A fiscal gap of zero means that no additional effort compared to 2009 is needed.

Source: OECD, Economic Outlook database.

Several explanations are behind the trend increase in states' debt. First, better information on subnational governments' financial positions, and lower borrowing costs have facilitated the development of an incipient debt market for sub-national governments. Since 2000 it has been a market practice for subnational governments to be rated by two agencies in order to access credit through the securities market. Currently all the states and about 100 municipalities are rated by at least two agencies (Fitch, 2011a), accounting approximately for $58 \%$ of all debt in the first quarter of 2011 , according to government figures. Sub-national governments are also required to register their debt with the finance ministry when debt is backed by federal transfers. Increased transparency and the broad use of credit risk ratings have allowed a better identification of risks triggering greater access to credit. Second, the creation of a trust fund (Fidecomiso Maestro) enabling the use of federal transfers as collateral for sub-national government borrowing has also been key for a more active participation of the banking and stock market in the financing of sub-central governments (IDB, 2009; Joumard, 2005). Third, the continuous growth of federal transfers has also facilitated greater access to credit, as transfers serve not only to pay for, but also to guarantee sub-nationals' debt.

The 2009 crisis has been an additional factor adding to increasing debt. Access to the federal stabilization fund (Fondo de Estabilización de Ingresos de las Entidades Federativas) provided a welcome stability to sub-national finances. But, the fall in federal transfers as a result of the slowdown in economic activity and the reduction in the oil price meant that subnational governments were severely hit by the crisis (Fitch 2012 and Revilla, 2010). The combination of rising spending and lower revenues, meant some states needed to issue debt in order to finance investments as part of their fiscal stimulus packages (OECD, 2012a). However, debt continued to increase even after 2009 in spite of a recovery in their revenues.

While at only $2.8 \%$ of states' GDP the growth in state indebtedness does not pose a systemic risk, however, such behaviour can eventually lead to debt servicing difficulties and hard-to-resist pressures on central governments to bail out states in difficulties. Pressures could be quite powerful as states have the responsibility of essential public services, such as education and health, as the 1990s sub-national debt crisis showed. In addition, some banks have built up their exposures to sub-sovereign borrowers substantially over the past few years, attracted by the perception of an implicit government guarantee and low capital usage (Banxico, 2011). Banking regulations exempt lending to states and municipalities from limits on large exposures if the loans have federal participations as a guarantee. The national banking commission (Comisión Nacional Bancaria y de Valores) has recently unveiled plans to withdraw such 
exemption, so that commercial bank lending (banca múltiple) to individual states and municipalities would be subject to the same large exposure limits - which are based on the capitalisation of banks - as all other loans. These are welcome. Credit reserves are a good measure to limit the risks on the banking sector and improve banks' risk management, but they should also cover development banks. Slightly less than a quarter of sub-sovereigns' lending is provided by development banks, according to government figures.

In addition to explicit debt, implicit liabilities stemming from state pension systems for public employees are high in about half of the states (Fitch, 2011a). Moreover, about one third of all states have recently introduced non-contributory pension pillars, which are financed through taxes (OECD, 2011b). Most municipalities lack a formal pension system and pension obligations are paid through current expenditure. Sub-national entities may also have important liabilities related to their decentralized agencies, particularly local public enterprises in the water, transportation or housing sector. Although a precise figure is hard to come by, given very sparse information, some estimates put contingent liabilities at $12 \%$ of GDP in 2010 (IMCO, 2010). The ratio of active to retired workers will continue to decrease in the coming decades, as population ages. And the burden of retirement benefits will grow for state governments as the pool of contributions from active workers continues to shrink.

Addressing the pension challenge will require in-depth reforms, including converting the defined benefit pension systems in most states to defined contribution systems based on individual accounts, as recommended in the 2011 Economic Survey of Mexico and more recently by González Anaya and Revilla (2012). The need for reform is particularly urgent in a few states that have less than 5 years of selfsufficiency or are even already making their pension payments out of current expenditure (Figure 16). For others the sustainability of the system is only secured until 2015 (Figure 3.16). The federal government should keep encouraging states to reform their pension systems and make use of the dedicated fund for the structural reform of pension systems (Fondo de Apoyo para la Reestructuración de Pensiones), which has been hardly used up to date. Better information on states' debt, including short term debt, as mandated by the new Law on Government Accounting, would also contribute to improve transparency and accountability, as well as better monitoring of the sustainability of public finances. Information on states and municipalities contingent liabilities should ideally be also available. An option would be for the Ministry's debt registry to cover not only states' debts, but also contingent liabilities. In addition, it would be important to improve the information on the number and wages of state employees, in particular in the education sector, which accounts for the bulk of states' employees, as to have better information on future pension payments and contingent liabilities. 


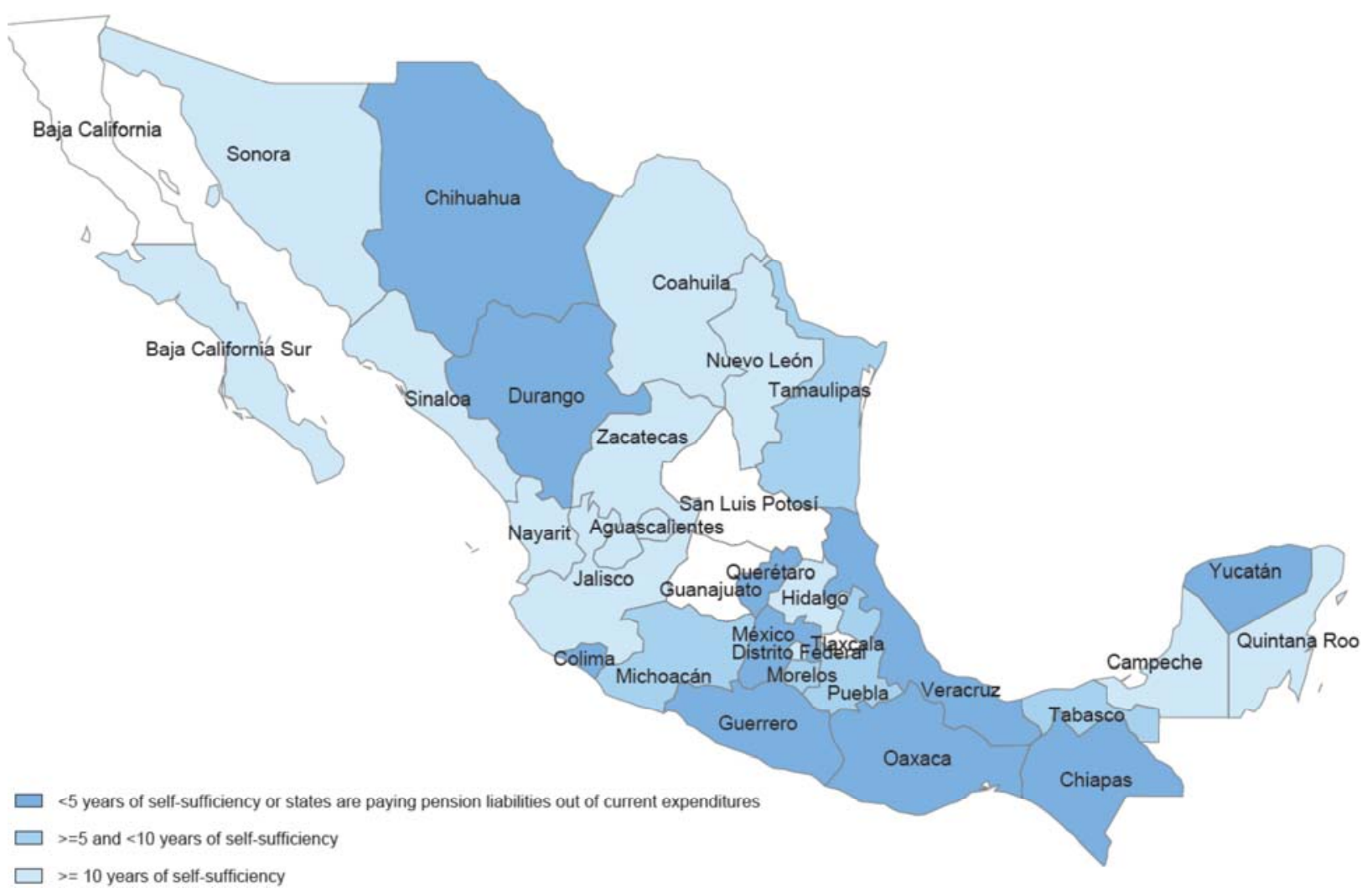

1. White denotes no data.

Source: Author analysis based on Fitch state reports over 2009-2012, as of June 2012

\section{Institutional arrangements to ensure greater fiscal discipline}

Broader reforms are nonetheless warranted to ensure greater fiscal discipline at the sub-national level. The current system does not promote fiscal responsibility and the instruments to secure fiscal discipline are weak, notwithstanding important progress in the past two decades. Following the 1990s sub-nationals' debt crisis, new rules were introduced to limit states' access to borrowing and to increase transparency. They also strengthened the federal government's commitment not to bail out sub-national institutions. In the past, upon a sub-national debt default, banks could ask the federal government to pay for the debt, as the federal government acted as a trustee in servicing the debt that had been collateralised with federal transfers (Joumard, 2005; Fedelino and Ter-Minassian, 2010). Now it is no longer the case.

However, the current system still has flaws. It relies mainly on market discipline, but several of the necessary conditions for market discipline to work as an effective instrument to impose hard budget constraints on sub-national governments are not in place. First, there is a large asymmetry between transfers and own revenues that can still lead to soft budget constraints and moral hazard. Second, subcentral governments, in particular states, have a rather privileged access to finance. While their own revenue raising autonomy is low, loans are often guaranteed with federal government transfers and are therefore perceived to be low risk. However, the guarantee implies that the lender has no incentives to assess if the sub-central government is committing too many of its transfers and would therefore have fiscal problems if the guarantees were to be exercised. Moreover, by having used their federal transfers as guarantees, local governments have a very limited ability to renegotiate their loans. Third, information on sub-national finances is at best scarce, and at worst unreliable, impairing the scrutiny of financial 
institutions. And finally, the history of past bailouts and discretionary transfers from the federal to subcentral governments hardly suggests the federal government will not bail out subnational governments if in trouble.

Relying mostly on market discipline is more of a problem given loose borrowing restrictions at the subnational level. The federal constitution imposes some conditions sub-national entities must comply with to access credit markets. Sub-national entities can only borrow in domestic currency, from domestic creditors, and to finance productive public investment (the so called golden rule). Each state is, however, responsible for setting its own limits on debt contracting. But very few states impose limits. And for those that do have them they are rather loose and easy to circumvent. Only five out of 32 states have set a limit on borrowing based on a percentage of the expenditure budget or certain revenue for each fiscal year (Annex Table A1.4), however, such limits crucially exclude outstanding debt.

Often short-term borrowing does not require legislative authorization, which is usually required for contracting and registering long-term debt (Annex Table A1.4). In addition, debt limits can also be exceeded if authorised by state congress. Finally, state laws typically restrict debt contracting for the financing of productive investment, but the definition of productive investment is very loose (IDB, 2009; ASF, 2011).

International evidence suggests a combination of fiscal rules at the sub-national level and market discipline works best, combined with strong credibility of no bail-out provisions, as to reduce moral hazard (IMF, 1997; Sutherland et al. 2005). Such rules can help to ensure fiscal discipline, but also to improve the coherence and coordination of overall macroeconomic objectives across levels of government. Mexico stands out among the OECD and Latin American countries as an exception by combining loose constraints on sub-national borrowing with the use of federal transfers as guarantees for the loans (Fedelino and TerMinassian, 2010). States should adopt additional prudential rules, such as rules on deficits. Such rules should also include tighter regulations on short term debt. Short term debt should only be allowed for liquidity purposes and rules should stipulate that such borrowing has to be repaid by the end of the fiscal year, as is done for example in the United States (IMF, 1997).

The role of the federal government should be to promote the implementation of fiscal rules and to ensure that the rules adopted by sub-national governments are mutually consistent, so the risk of freeriding behaviours is minimised. The federal government should also promote the implementation of indirect debt ceilings by setting a limit on the share of transfers that can be used to underwrite sub-national government debt and/or make the implicit guarantee conditional on sub-central governments implementing more prudent fiscal rules. A better distinction between current expenditure and capital expenditure should be applied to ensure long term debt is efficiently used to finance public investment. To be effective, such rules should also strictly limit the scope of off-budget operations, such as for instance through local enterprises and financial institutions, to avoid fiscal gimmickry (Sutherland et al. 2005). For instance, evidence from the United States suggests that budget balance requirements have only moderate impacts partly due to states evading the constraint by shifting resources between controlled funds and other funds that are unconstrained by the fiscal rule. The growth of debt in Spanish public enterprises is another example of how evasion of strict budget balance requirements can manifest itself, at least temporarily (OECD, 2005). In addition to strengthened rules, given the history of bail outs of insolvent sub-national governments by the central government, a firm and sustained refusal to engage in similar operations should be maintained to firmly keep market participants' expectations and behaviours.

A bill that would make constitutional changes to impose stricter controls on subnational governments' debt passed the Senate in April 2013. It will need to pass the lower house and be ratified by a majority of state legislatures. If passed, the law would allow the federal legislature to enact laws on fiscal responsibility and coordination, plus create a single debt registry at the Ministry of Finance to monitor 
subnationals' debt. It would also establish a mechanism to reduce borrowing costs for highly indebted subnational governments with Senate approval, by obtaining a federal government guarantee conditional on subnationals fulfilling pre-agreed financial objectives. Moreover, debt contracting by states would require two-thirds approval by state legislatures rather than a simple majority vote, while specifying that debt should not be used to finance current expenditures and it needs to be repaid by the end of the contracting administration.

Stricter fiscal rules, such as rules on deficits or debt rules are likely to make fiscal policy more procyclical. A possible solution would be to define fiscal rules in cyclically adjusted terms, but it is computationally difficult to assess local cycles. A more feasible possibility would be to set up budget stabilisation funds ("rainy day funds") at the state level to save extra revenues during upswings, as in the United States (NASBO, 2007). In combination with rules calling for balanced budgets, rainy day funds have provided a transparent mechanism to save during good times, and have proved useful in smoothing the impact of cyclical revenue fluctuations on state expenditures (Ter-Minassian, 2007). Better coordination between the central and state governments in setting fiscal objectives, for instance through a forum, as those existing in Germany, as described above, could also contribute to better align fiscal policies during the cycle. Such a forum could also help to strengthen fiscal discipline by strengthening political commitments and peer pressure.

For fiscal rules and market discipline to work, timely and reliable information on sub-national governments' financial positions, including on contingent liabilities and on fiscal activities, such as those related to public private partnerships (PPPs) should be available to allow better monitoring of rule compliance and better monitoring by lenders. The new law on Government Accounting, which mandates states and municipalities to publish their accounts on the Internet including information on their debt positions, should certainly help. To strengthen monitoring the federal government could also consider setting up an external auditing system. Such institution would help not only to monitor the compliance with fiscal rules, but could also spur sub-central government innovation and moving towards best practice in the delivery of information.

\section{Concluding remarks}

Successfully reforming Mexico's fiscal federal system will require a consistent and well-coordinated package of measures and substantial political will, given the complexity of the current system and vested interests. Box 5 summarises the key features of such a reform package. It will not be easy. Mexico could, however, reap significant efficiency and equity gains if it were to pursue the necessary reforms. A reform of this type would be a medium- to long-term project. But it should not be delayed. The government should take advantage of the current good economic and fiscal situation, to reform Mexico's intergovernmental fiscal relations. Evidence from OECD countries suggests that a good economic and fiscal situation is key for the success of such reforms (Blöchliger and Vammalle, 2012).

As preliminary steps, the reform needs to improve the assignment of spending responsibilities to each level of government to reduce overlaps. Greater efforts will also be needed to gather the information needed to assess sub-nationals' spending needs and use of funding. Better coordination between subnationals and the federal government, implementing homogenous accounting across all levels of government and strengthening sub-nationals' fiscal rules should also be given priority to enhance macroeconomic management, fiscal sustainability and transparency. Then broader reforms to improve the efficiency and redistributive features of the transfer system could be tackled. Bundling efficiencyenhancing elements with distributional objectives could help to spread reform benefits across different jurisdictions and actors and help to overcome their resistance. This could then set the stage for overcoming sub-nationals' resistance to tax more and successfully increase sub-national revenue autonomy. Once subnationals' revenue autonomy is higher, federal governments transfers could then be limited to avoid duplication and to improve efficiency. 


\section{Box 5. Recommendations to improve fiscal relations across levels of government}

- Improve sub-nationals' spending efficiency and effectiveness by clarifying spending responsibilities for lower levels of government in health and education.

- Establish a harder budget constraint on subnational governments to improve their tax collection by limiting further increases in transfers and avoiding extraordinary transfers and promoting the implementation of limits on deficits and debt ceilings.

- $\quad$ Grant more tax powers to states by allowing states to charge income and consumption taxes over and above the federal ones, but collected by the federal tax administration. Strengthen property tax revenues by updating property registries, increasing rates, removing exemptions and improving collection, by allowing the federal or state tax administrations to collect the tax.

- Improve the functioning and transparency of federal transfers by setting up and applying clear and measurable formulae for the allocation of transfers whenever these don't exist, by giving greater weight to needs and higher incentives to states to provide better services. Earmarked transfers for health and education should also take cost differentials in service provision among regions into account in the allocation of funding to reduce inequities in access.

- Enhance the system's equity by setting-up a system of federal transfers to most deprived areas. Reduce the volatility of federal government transfers by including a smoothing mechanism in the revenue sharing formulas and consider setting-up budget stabilisation funds to smoothen sub-national revenues.

- Improve public financial management by developing and implementing multi-year budgeting at the state level, with a focus on expenditure performance and effectiveness, and on outcomes in the public sector. Improve fiscal coordination between the federal and state government, by for instance, setting up an institution for discussion on sub-national budgets and financial plans.

- Continue efforts to gradually reform states' defined pension systems toward defined contribution systems.

- Encourage the use of a more precise definition of productive public investment in state debt laws.

- Adopt stronger prudential banking regulations for lending to states and municipalities based on bank capitalisation.

- Fully implement the new general government accounting law to ensure greater transparency and accountability of local budgets, and ensure that it is effectively followed in all states and municipalities.

\section{BIBLIOGRAPHY}

Ahmad, E. and Brosio, G. (2006), "Handbook of Fiscal Federalism”, Edward Elgar Publishing Inc.

Álvarez Estrada, D. (2009), “Tributación directa en América Latina: Equidad y Desafíos. Estudio del Caso de Mexico", Serie Macroeconomía del Desarrollo No. 91, Proyecto CEPAL-GIZ (LC/L.3093-P), Santiago de Chile.

Andrews, D., Caldera Sánchez, A. and Johansson A. (2011), "Housing Markets and Structural Policies in OECD Countries", OECD Economics Department Working Papers, No. 836. 
Auditoría Superior de la Federación (2008), "Informe del Resultado de la Fiscalización Superior de la República".

Auditoría Superior de la Federación (2009), "Ramo General 33, Evaluación Fondo de Aportaciones para los Servicios FASSA".

Auditoría Superior de la Federación (ASF) (2011), “Análisis de la Deuda Pública de las Entidades Federativas y Municipios, 2000-Marzo 2011”, Cámara de Diputados.

Banxico (2011), "Reporte sobre el sistema financiero: Septiembre 2011”, Banco Central de México.

Bird, R. (1999), "Rethinking subnational taxes: A new look at tax assignments" IMF Working Papers, No. 165.

Bird, R. (2011), "Subnational taxation in developing countries: a review of the literature", Journal of International Commerce, Economics and Policy, Vol. 2, No. 1, pp. 139-161.

Blöchliger, H. and Egert, B. (2013), "Measuring the cyclical properties intergovernmental grants", OECD Economics Department Working Paper, forthcoming.

Blöchliger, H. and Vammalle, C. (2012), "Reforming Fiscal Federalism and Local Government: Beyond the Zero-Sum Game", OECD Network on Fiscal Relations across Levels of Government Working Papers, forthcoming.

Blöchliger, H., Brezzi, M. Charbit, C., Migotto, Pinero-Campos, J.M. and Vammalle, C. (2010), "Fiscal Policy across Levels of Government in Times of Crisis", OECD Network on Fiscal Relations across Levels of Government Working Papers, No. 12.

Blöchliger, H. and Petzold, O. (2009), "Taxes and grants: On the revenue mix of sub-central governments", OECD Network of Fiscal Relations across Levels of Government Working Papers, No. 7.Blöchliger, H., Merk, O. Charbit, C., Mizell, L. (2007), "Fiscal equalisation in OECD countries", OECD Network on Fiscal Relations Across Levels of Government, Working Papers, No. 4.

Boadway R. and Shah, A. (2009), "Fiscal Federalism: Principles and Practices of Multiorder Governance", Cambridge University Press.

Bordignon and Turati (2005), "Bailing Out Expectations and Health Expenditure in Italy: an empirical approach", Universidad Catolica de Milano, mimeo.

Cabrera-Castellanos, L.F and Lozano-Cortés, R. (2008), "Decentralization and Fiscal Federalism in Mexico", MPRA Working Papers, No. 10572.

Cabrero, E. and Martínez-Vazquez, J. (2000), “Assignment of Spending Responsibilities and Service Delivery" in Giugale, Marcelo and S. Webb (eds.), Achievements and Challenges of Fiscal Decentralization, The World Bank, Washington, DC.

Campos, M., Jarillo, B. and Santibañez, L. (2010), "Gasto en Educación: la Eficiencia del Financiamiento Educativo en México", México Evalúa, Centro de Análisis de Políticas Públicas.

Careaga, M. and B. R. Weingast (2003), "Fiscal Federalism, Good Governance, and Economic Growth in Mexico", Dani Rodrik (ed.), In Search of Prosperity: Analytic Narratives on Economic Growth, Princeton University Press.

Castañeda, L.C. and Pardinas, J. E. (2012), "Sub-national revenue mobilization in Mexico", InterAmerican Development Bank Working Papers, No. IDB-WP-354. 
CONEVAL (2011a), "Informe de Evaluación de la Política de Desarrollo Social en México 2011", Consejo Nacional de Evaluación de la Política Social, México.

CONEVAL (2011b), "El Ramo 33 en el desarrollo social en México: evaluación de ocho fondos de política pública", Consejo Nacional de Evaluación de la Política Social, México.

Cours des Comptes (2009), "Bilan d'étape de l'intercommunalité en France”.

Deutsche Bank (2011), “Stability Council: Financial Inspector of Germany’s Länder”, Deutsche Bank Research.

De la Maisonneuve, C. and Oliveira Martins, J. (2013), "Public spending on health and long-term care: a new set of projections", OECD Economics Department Working Papers, forthcoming.

Fedelino, A. and Ter-Minassian, T. (2010), "Making Fiscal Decentralisation Work: Cross-Country Experiences", IMF Occasional Papers, No. 271, International Monetary Fund, Washington DC.

Fernandez Martínez, M. A. (2011), "Teachers, protests, and parties: the political economy of educational transfers in Mexico", Duke University, mimeo.

Fierro Evans, C., Tapia García, G y Rojo Pons F. (2009), "Descentralización educativa en Mexico: un recuento analítico", Implementación de políticas educativas, México, OECD.

Fitch (2012), "Tendencias y Perspectivas en las Calificaciones de Entidades Subnacionales en México", Fitch Ratings, International Finance México, October.

Fitch (2011a), "Marco Institucional de los Gobiernos Subnacionales en México", Fitch Ratings, International Public Finance México, September.

Fitch (2011b), "Mexican Sub-nationals' Credit Performance Continues Downward Trend", Fitch Ratings, International Public Finance Mexico, December.

Fitch (2011c), "Normas Prudenciales en Estados y Municipios: Importancia de su Aplicación Oportuna", Fitch Ratings México.

Garza Ibarra, C. A. (2011), "Fiscal federalism in Mexico", presentation, Ministry of Finance and Public Debt, Mexico.

González Anaya, J.A. and Revilla, E. (2012), “Mexico’s Fiscal Federalism”, mimeo.

IDB (2009), "Panorama de financiamiento de infrastructure con capitales privados en Mexico", Interamerican Development Bank.

IMCO (2010), “Indice de Competitividad Estatal 2010: La Caja Negra del Gasto Público:”, Instituto Mexicano de Competitividad.

IMF (1997), "Fiscal Federalism in Theory and Practice", International Monetary Fund, Washington DC.

Indetec (2011), "Debilidad de las Tasas y Tarifas del Impuesto Predial en México" Presentation at Jornada Regional de Catastro y Tributación Inmobiliaria.

Joumard, I. (2005), "Getting the most of public sector decentralization in Mexico", OECD Economics Department Working Papers, No. 453.

Joumard, I. and Kongsrud, P. M. (2003), "Fiscal relations across levels of government", OECD Economic Studies, Vol. 36, No. 1. 
Joumard. I., André C. and Nicq, C. (2010), "Health Care Systems: Efficiency and Institutions", OECD Economics Department Working Papers, No. 769.

Martínez-Fritscher and Rodríguez-Zamora C. (2011), "An Evaluation of the 1997 Fiscal Decentralization Reform in Mexico: The Case of the Health Sector”, Banco de México Working Papers, No. 2011-16.

Merino, Gustavo (2003), "Descentralización del sistema de salud en el contexto del federalismo", In: Caleidoscopio de la Salud, de la investigación a las políticas, y de las políticas a la acción. México: Fundación Mexicana para la Salud, pp. 195-207.

NASBO (2007), Fiscal Survey of the States, National Association of State Budget Officers, Washington, DC.

Oates, W. and Schwab, R. (1988), "Economic competition among jurisdictions: efficiency-enhancing or distortion-inducing?", Journal of Public Economics, No. 35.

OECD (2004a), OECD of Reviews of Regulatory Reform: Mexico, Paris.

OECD (2004b), OECD Territorial Reviews, Mexico City, Paris.

OECD (2005), OECD Economic Surveys: Spain, Paris.

OECD (2006a), "Workshop Proceedings: The Efficiency of Sub-Central Spending", OECD Fiscal Network Workshop on Performance Indicators and Local Government Collaboration, Paris, May.

OECD (2006b), "Fundamental reform of personal income tax", OECD Tax Policy Studies, Paris.

OECD (2006c), OECD Territorial Review, Competitive Cities in the Global Economy, Paris.

OECD (2010a), Improving Schools: Strategies for Action in Mexico, Paris.

OECD (2010b), Regional Development Policies in OECD Countries, Paris.

OECD (2010c), OECD Public Governance Reviews: Finland Working Together to Sustain Success, Paris.

OECD (2010d), Financing Water Resources Management in Mexico, Paris.

OECD (2010e), Reviews of Regulatory Reform: Australia, Towards a Seamless National Economy, Paris.

OECD (2011a), Lessons from PISA for Mexico: Strong Performers and Successful Reformers in Education, Paris.

OECD (2011b), Economic Surveys: Mexico, Paris.

OECD (2012), Equity and Quality in Education: Supporting Disadvantaged Students and Schools, Paris

OECD (2012a), OECD Territorial Reviews: Chihuahua, Paris.

OECD (2012b), Economic Surveys: Norway, Paris.

OECD (2012c), "Guide to Improve the Regulatory Quality of State and Municipal Formalities and Strengthen Mexico's Competitiveness", Mexico City.

OECD (2012d), Mexico Environmental Policy Review, Paris.

OECD (2012e), "Framework conditions for private sector participation in water infrastructure in Mexico", June. 
OECD (2012f), Promoting Growth in All Regions, Paris.

OECD (2013a), Improving Education in Puebla: an OECD perspective on basic and upper secondary education, Paris.

OECD (2013b), Making Water Reform Happen in Mexico, Paris

Revilla, E. (2010), "Subnational debt restructuring in Mexico: a tale of two crises", mimeo.

Santiago, P., I. McGregor, D. Nusche, P. Ravela and D. Toledo (2012), OECD Reviews of Evaluation and Assessment in Education: Mexico, OECD, Paris.

Salazar Domínguez, J. G. (2011), "The Political Determinants of Resource Allocation in Mexican Municipalities: the Fund for Municipal Social Infrastructure", University of Sussex, DPhil thesis.

Schwellnus, C (2009), "Achieving Higher Performance: Enhancing Spending Efficiency in Health and Education in Mexico," OECD Economics Department Working Papers, No. 732.

Smith, H. J. (2012), "Fiscal Decentralization and Development: An Analysis of City Governments in Argentina and Mexico, 1980-2010", Florida International University, mimeo.

Sutherland, D., Price, R. and Joumard, I. (2005), "Fiscal Rules for Sub-central governments: Design and Impact", OECD Economics Department Working Papers, No. 465.

Ter-Minassian, T. and Jiménez, J. P. (2011), "Macroeconomic Challenges of Fiscal Decentralization in Latin America in the Aftermath of the Global Financial Crisis", ECLAC Working Papers.

Ter-Minassian, T. (2007), "Fiscal Rules for Subnational Governments: Can They Promote Fiscal Discipline?", OECD Journal on Budgeting, Vol. 6, No. 3.

UNPD (2011), "Informe sobre Desarrollo Humano de los Pueblos Indígenas en México", Programa de las Naciones Unidas para el Desarrollo.

Villanueva Sánchez, P. (2010), "Impacto de la descentralización de la educación básica y normal en México sobre el gasto en nómina magisterial de los estados, 1999-2004" Economía Mexicana Nueva Epoca, Vol. XIX, No. 2.

Von Haggen, J. and Hepp, R. (2001), "Regional Redistribution and Risk Sharing in the German Federation", CEPR Discussion Papers.

Warren, N. (2006) "Benchmarking Australia's Intergovernmental Fiscal Arrangements", New South Wales Government. 
ECO/WKP(2013)70

\section{ANNEX A1}

Table A1.1. Non-earmarked transfers (Participaciones federales, Ramo 28)

\begin{tabular}{|c|c|c|c|c|c|}
\hline Fund & Purpose & Funding & $\begin{array}{l}\text { Distribution } \\
\text { criteria }\end{array}$ & Recipient & $\begin{array}{l}\text { \% Ramo } \\
28(2010)\end{array}$ \\
\hline $\begin{array}{l}\text { Fondo General de } \\
\text { Participaciones (FGP)* }\end{array}$ & $\begin{array}{l}\text { Revenue } \\
\text { sharing with } \\
\text { states and } \\
\text { municipalities }\end{array}$ & $20 \%$ of RFP & $\begin{array}{l}60 \%) \text { State } \\
\text { GDP growth; } \\
(30 \%) \text { local } \\
\text { revenue growth; } \\
(10 \%) \text { local } \\
\text { revenue level }\end{array}$ & $\begin{array}{l}\text { State and } \\
\text { municipalities }\end{array}$ & $86 \%$ \\
\hline $\begin{array}{l}\text { Fondo de Fomento } \\
\text { Municipal (FFM) }\end{array}$ & $\begin{array}{l}\text { Revenue } \\
\text { sharing with } \\
\text { municipalities }\end{array}$ & $1 \%$ of RFP & $\begin{array}{l}\text { Municipal } \\
\text { revenue } \\
\text { (property tax } \\
\text { and water fees) } \\
\text { weighted by } \\
\text { state population }\end{array}$ & Municipalities & $4 \%$ \\
\hline $\begin{array}{l}\text { Fondo de Fiscalización } \\
\text { (FOFIE)) }\end{array}$ & $\begin{array}{l}\text { Incentive for } \\
\text { enforcement } \\
\text { of tax laws }\end{array}$ & $1.25 \%$ of RFP & $\begin{array}{l}\text { Measures of } \\
\text { local efforts of } \\
\text { enforcement of } \\
\text { tax laws }\end{array}$ & $\begin{array}{l}\text { State and } \\
\text { municipalities }\end{array}$ & $5 \%$ \\
\hline $\begin{array}{l}3.17 \% \text { of Derecho } \\
\text { Adicional (Special Oil } \\
\text { royalty) }\end{array}$ & $\begin{array}{l}\text { Resources for } \\
\text { oil producing } \\
\text { municipalities }\end{array}$ & $\begin{array}{l}3.17 \% \text { of a } \\
\text { special oil } \\
\text { royalty }\end{array}$ & $\begin{array}{l}\text { Municipal } \\
\text { revenue } \\
\text { (property tax } \\
\text { and water rights) }\end{array}$ & Municipalities & $0.30 \%$ \\
\hline $\begin{array}{l}0.136 \% \text { de Recaudación } \\
\text { Federal Participable }\end{array}$ & $\begin{array}{l}\text { Resources for } \\
\text { municipalities } \\
\text { on the border }\end{array}$ & $\begin{array}{l}1.136 \% \text { of } \\
\text { RFP }\end{array}$ & $\begin{array}{l}\text { Municipal } \\
\text { revenue } \\
\text { (property tax } \\
\text { and water rights) }\end{array}$ & Municipalities & $0.70 \%$ \\
\hline $\begin{array}{l}\text { Fondo de Extracción de } \\
\text { Hidrocarburos (FEXHI) }\end{array}$ & $\begin{array}{l}\text { Compensate } \\
\text { for oil and gas } \\
\text { extraction }\end{array}$ & $\begin{array}{l}0.6 \% \text { of main } \\
\text { oil royalty }\end{array}$ & $\begin{array}{l}\text { Oil and gas } \\
\text { production }\end{array}$ & $\begin{array}{l}\text { State and } \\
\text { municipalities }\end{array}$ & $1 \%$ \\
\hline $\begin{array}{l}\text { Impuesto Especial sobre } \\
\text { la Producción y Servicios } \\
\text { (IEPS) }\end{array}$ & $\begin{array}{l}\text { "Sin tax" } \\
\text { revenue } \\
\text { sharing with } \\
\text { states and } \\
\text { municipalities }\end{array}$ & $\begin{array}{l}80 \% \text { tobacco; } \\
20 \% \text { beer and } \\
\text { alcohol }\end{array}$ & $\begin{array}{l}\% \text { sales of } \\
\text { tobacco, beer } \\
\text { and alcohol } \\
\text { relative to the } \\
\text { national average }\end{array}$ & $\begin{array}{l}\text { State and } \\
\text { municipalities }\end{array}$ & $2 \%$ \\
\hline $\begin{array}{l}\text { Fondo de compensación } \\
\text { (FOCO) }\end{array}$ & $\begin{array}{l}\text { Compensate } \\
\text { the } 10 \text { poorest } \\
\text { states }\end{array}$ & $\begin{array}{l}\text { Two- } \\
\text { elevenths of } \\
\text { the local } \\
\text { gasoline tax } \\
\text { collection }\end{array}$ & $\begin{array}{l}\text { Inverse of nonoil } \\
\text { GDP per capital }\end{array}$ & $\begin{array}{l}\text { State and } \\
\text { municipalities }\end{array}$ & $1 \%$ \\
\hline
\end{tabular}

Note: RFP stands for Recaudación Federal Participable, the pool of federal revenues that is shared with states and municipalities. It includes the income tax, VAT, all other federal taxes and oil revenues. It does not include revenue from public enterprises, federal government funding, and certain other sources of nontax revenue. States are required by lax to share at least $20 \%$ of these resources with municipalities. Funds which allocation formulas were modified in the last 2007 reform are marked with an asterisk.

Source: Author's work based on González Anaya and Revilla (2012) and Garza Ibarra (2011) and other documentation from the Ministry of Finance. 
ECO/WKP(2013)70

Table A1.2: Earmarked transfers (Aportaciones federales, Ramo 33)

\begin{tabular}{|c|c|c|c|c|c|}
\hline Fund & Purpose & Funding & Distribution criteria & Recipient & $\begin{array}{l}\% \text { Ramo } \\
33(2010)\end{array}$ \\
\hline $\begin{array}{l}\text { Fondo de aportaciones para la } \\
\text { educación básica (FAEB)* }\end{array}$ & Basic education & $\begin{array}{l}\text { Theoretically } \\
\text { enough money } \\
\text { to cover } \\
\text { payroll. } \\
\text { Typically } \\
\text { negotiated } \\
\text { during the } \\
\text { budget } \\
\text { process. }\end{array}$ & $\begin{array}{l}(50 \%) \text { Public student enrollment in } \\
\text { state; }(20 \%) \text { state's spending in } \\
\text { education; }(20 \%) \text { states with per } \\
\text { student FAEB below national average; } \\
(10 \%) \text { education quality index }\end{array}$ & State & 59 \\
\hline $\begin{array}{l}\text { Fondo de aportaciones para } \\
\text { los servicios de Salud (FASSA) }\end{array}$ & Health services & $\begin{array}{l}\text { Theoretically } \\
\text { enough money } \\
\text { to cover } \\
\text { payroll. } \\
\text { Typically } \\
\text { negotiated } \\
\text { during the } \\
\text { budget } \\
\text { process }\end{array}$ & $\begin{array}{l}\text { Mostly based on number of } \\
\text { beneficiaries, with a small weight given } \\
\text { to health needs, state health spending } \\
\text { and efficiency in spending }\end{array}$ & State & 12 \\
\hline $\begin{array}{l}\text { Fondo de Aportaciones para la } \\
\text { Infraestructura Social (FAIS) }\end{array}$ & $\begin{array}{l}\text { Social and rural } \\
\text { infrastructure }\end{array}$ & $\begin{array}{l}0.303 \% \text { of } \\
\text { RFP } \\
2.197 \text { of RFP }\end{array}$ & $\begin{array}{l}\text { Relative state's needs compared to the } \\
\text { national average measured by: } \\
\text { extreme poverty, per capita income, } \\
\text { schooling, housing size, water and } \\
\text { drainage quality. }\end{array}$ & $\begin{array}{c}\text { State } \\
\text { Municipalities }\end{array}$ & 9 \\
\hline $\begin{array}{l}\text { Fondo para el fortalecimiento } \\
\text { de Municipal y Demarcaciones } \\
\text { Territoriales del DF ( } \\
\text { FORTAMUN-DF) }\end{array}$ & $\begin{array}{l}\text { Municipal } \\
\text { strengthening }\end{array}$ & $2.56 \%$ of RFP & $\begin{array}{l}2.35 \% \text { to states based on population. } \\
\text { States distribute to municipalities } \\
\text { based on population.0.2123\% } \\
\text { distributed to the Federal District (DF). } \\
\text { The DF distributes funds to } \\
\text { municipalities based on their resident } \\
\text { and floating population. }\end{array}$ & Municipalities & 9 \\
\hline $\begin{array}{l}\text { Fondo de Aportaciones } \\
\text { Multiples (FAM) }\end{array}$ & $\begin{array}{l}\text { Social assistance } \\
\text { and education } \\
\text { infrastructure }\end{array}$ & $\begin{array}{l}0.814 \% \quad \text { of } \\
\text { RFP }\end{array}$ & Social vulnerability index & State & 3 \\
\hline $\begin{array}{l}\text { Fondo de Aportaciones para la } \\
\text { Educación Tecnológica y de } \\
\text { Adultos (FAETA) }\end{array}$ & $\begin{array}{l}\text { Promote adult } \\
\text { education and } \\
\text { alphabetization }\end{array}$ & $\begin{array}{l}\text { Theoretically } \\
\text { enough money } \\
\text { to cover } \\
\text { payroll. } \\
\text { Typically } \\
\text { negotiated } \\
\text { during the } \\
\text { budget } \\
\text { process. }\end{array}$ & Schooling facilities and workers & State & 1 \\
\hline $\begin{array}{l}\text { Fondo de aportaciones para la } \\
\text { Seguridad Pública (FASP) }\end{array}$ & Public security & $\begin{array}{l}\text { during the } \\
\text { budget } \\
\text { process }\end{array}$ & $\begin{array}{l}\text { Population, delinquency and criminality } \\
\text { indices }\end{array}$ & State & 2 \\
\hline $\begin{array}{l}\text { Fondo de Aportaciones para el } \\
\text { Fortalecimiento de las } \\
\text { Entidades Federativas } \\
\text { (FAFEF)* }\end{array}$ & $\begin{array}{l}\text { Financial needs } \\
\text { and pensions }\end{array}$ & $1.4 \%$ of RFP & Inverse of GDP per capita & State & 5 \\
\hline
\end{tabular}

Note: FP stands for Recaudacion Federal Participable, the pool of federal revenues that is shared with states and municipalities. It includes the income tax, VAT, all other federal taxes and oil revenues. It does not include revenue from public enterprises, federal government funding, and certain other sources of nontax revenue. States are required by law to share at least $20 \%$ of these resources with municipalities. Funds which allocation formulas were modified in the last 2007 reform are marked with an asterisk.

Source: Author's work based on González Anaya and Revilla (2012) and Garza Ibarra (2011) and other documentation from the Ministry of Finance. 
ECO/WKP(2013)70

Table A1.3. Assignments of taxes to sub-national governments

\begin{tabular}{|c|c|c|}
\hline Type of tax & Advantages & Disadvantages \\
\hline \multirow[t]{4}{*}{ Property and land taxes } & -Immobile tax base & $\begin{array}{l}\text {-Difficult and often costly administration (especially in } \\
\text { determining the value of the property tax bases and setting up } \\
\text { well-functioning cadastres), often resulting in low yield. }\end{array}$ \\
\hline & -Visible & -Highly visible, so often reforms are politically difficult. \\
\hline & -Stable yield & -Raise equity issues \\
\hline & -Indirectly linked to benefits & \\
\hline \multirow[t]{5}{*}{$\begin{array}{l}\text { User fees and charges (e.g. } \\
\text { waste collection, water } \\
\text { management, road tolls) }\end{array}$} & -Low mobility tax base & $\begin{array}{l}\text {-Generally low yield, because of distributional/political } \\
\text { considerations. }\end{array}$ \\
\hline & $\begin{array}{l}\text {-No obvious horizontal or vertical } \\
\text { imbalance problems }\end{array}$ & -Low cost-efficiency \\
\hline & -Visible & $\begin{array}{l}\text {-Raise equity concerns if applied to core goods such as } \\
\text { education, health care and social assistance }\end{array}$ \\
\hline & -Linked to benefits & -Legal constraints may exist in setting charges \\
\hline & & $\begin{array}{l}\text {-High implementation costs in some cases (administrative and } \\
\text { estimation of individualised consumption) }\end{array}$ \\
\hline \multirow[t]{3}{*}{ Personal income tax } & -Buoyant revenues & -May create or aggravate horizontal imbalances \\
\hline & -Visible (increases accountability) & $\begin{array}{l}\text {-In areas where average incomes are below threshold, } \\
\text { insufficient yield; also, as most people would not pay, the price- } \\
\text { signal effect of the tax is weakened. }\end{array}$ \\
\hline & $\begin{array}{l}\text {-Cost-effective if piggybacked on } \\
\text { national taxation }\end{array}$ & $\begin{array}{l}\text {-If levied at different rates among jurisdictions, it may create } \\
\text { distortions if people are mobile. }\end{array}$ \\
\hline \multirow[t]{4}{*}{ Sales and excise taxes } & $\begin{array}{l}\text {-No horizontal or vertical imbalance } \\
\text { problems }\end{array}$ & $\begin{array}{l}\text {-May create cross-border shopping if levied at different rates } \\
\text { among subnational jurisdictions. }\end{array}$ \\
\hline & -Visible & \\
\hline & -Easy to administer & \\
\hline & $\begin{array}{l}\text {-Some benefit argument e.g. alcohol } \\
\text { and tobacco (if subnational } \\
\text { responsible for health) vehicles and } \\
\text { fuel (if subnational responsible for } \\
\text { roads) }\end{array}$ & \\
\hline \multirow[t]{2}{*}{ VAT } & $\begin{array}{l}\text {-If properly designed and } \\
\text { administered, it could be a good local } \\
\text { tax. }\end{array}$ & -Complex tax administration \\
\hline & & $\begin{array}{l}\text {-If applied on destination principle, border controls between local } \\
\text { jurisdictions required; if applied on origin principle, tax exporting } \\
\text { and transfer pricing may arise. }\end{array}$ \\
\hline \multirow[t]{2}{*}{ Payroll tax } & -Low administrative costs & $\begin{array}{l}\text {-Act as a barrier to formal employment and may discourage } \\
\text { innovation by imposing a heavy burden on newly created firms } \\
\text { with low profits. }\end{array}$ \\
\hline & -High revenues & $\begin{array}{l}\text {-Weak link to benefits if commuting between different } \\
\text { jurisdictions is common, as revenues are collected at the place } \\
\text { of employment, as opposed to the place of residence. }\end{array}$ \\
\hline \multirow[t]{3}{*}{ Corporate income tax } & $\begin{array}{l}\text {-Sometimes seen as a bit of a benefit } \\
\text { tax. }\end{array}$ & $\begin{array}{l}\text {-Mobile tax bases and complex administration make it suitable } \\
\text { for collection by the centre. }\end{array}$ \\
\hline & & -Highly cyclical \\
\hline & & -Geographically concentrated \\
\hline \multirow[t]{3}{*}{ Resource taxes } & & -Significant horizontal imbalances \\
\hline & & -Difficult to administer \\
\hline & & -Excessively volatile \\
\hline
\end{tabular}

Source: Author's work based on Bird (1999), Blöchliger and Petzold (2009), Fedelino and Ter-Minassian (2010), Joumard and Kongsrud (2003). 
Table A1.4. Debt limits by state

\begin{tabular}{|c|c|c|c|c|c|c|c|}
\hline \multirow[b]{2}{*}{ State } & \multicolumn{3}{|r|}{ Long term debt } & \multicolumn{4}{|c|}{ Short term debt } \\
\hline & $\begin{array}{c}\text { Need } \\
\text { authorizatio } \\
\mathrm{n} \text { by state } \\
\text { government }\end{array}$ & $\begin{array}{l}\text { Limits on } \\
\text { state debt }\end{array}$ & Base for debt ceilings & $\begin{array}{l}\text { Is public } \\
\text { debt? }\end{array}$ & $\begin{array}{l}\text { Has to be } \\
\text { registered? }\end{array}$ & $\begin{array}{l}\text { Should be } \\
\text { guaranteed? }\end{array}$ & $\begin{array}{l}\text { Debt } \\
\text { restructuring } \\
\text { is prohibited }\end{array}$ \\
\hline Aguascalientes & Yes & No & $\ldots$ & No & Ambiguos & No & No \\
\hline Baja California & Yes & Yes & $\begin{array}{l}\text { Capital and interest payments over first } 12 \text { months } \\
\text { should not exceed } 22 \% \text { of state's spending. }\end{array}$ & n.a. & n.a. & n.a. & n.a. \\
\hline Baja California Sur & Yes & No & $\ldots$ & No & Ambiguos & No & No \\
\hline Campeche & Yes & Yes & Debt equivalent to $10 \%$ state's spending. & Yes & Yes & No & No \\
\hline Chiapas & Yes & Yes & $\begin{array}{l}\text { Debt equivalent to } 25 \% \text { state's own revenues and } \\
\text { non conditional grants (participaciones). }\end{array}$ & Yes & Yes & No & No \\
\hline Chihuahua & Yes & No & $\begin{array}{l}\text { Debt ceiling only applied to municipal debt. Debt } \\
\text { cannot exceed the period of } 2 \text { administrations and } \\
\text { should not exceed } 10 \% \text { of the budget in the } \\
\text { preceding fiscal year when contracts were signed. }\end{array}$ & Yes & Yes & No & No \\
\hline Coahuila & Yes & No & $\ldots$ & Yes & No & Yes & No \\
\hline Colima & Yes & No & $\ldots$ & Yes & Yes & No & No \\
\hline Distrito Federal & Yes & No & $\ldots$ & Yes & Yes & No & No \\
\hline Durango & Yes & No & $\begin{array}{l}\text { In addition to program funding approved by the } \\
\text { state Congress, additional debt can be authorized } \\
\text { if it doesn't exceed } 5 \% \text { ordinary revenues during } \\
\text { the fiscal year when debt is taken. }\end{array}$ & Yes & Yes & Yes & Yes \\
\hline Estado de México & Yes & No & Debt ceiling only applies to municipalities. & No & Ambiguos & Yes & No \\
\hline Guanajuato & Yes & Yes & $\begin{array}{l}\text { Debt may be contracted up to a net amount of } 10 \% \\
\text { of the total budget for the fiscal year when is } \\
\text { taken. }\end{array}$ & & & & \\
\hline Guerrero & Yes & No & $\ldots$ & Yes & Yes & No & No \\
\hline Hidalgo & Yes & No & Debt ceiling only applied to short term debt & No & No & Yes & Yes \\
\hline Jalisco & Yes & Yes & $\begin{array}{l}\text { Debt may be contracted up to a net amount of } 10 \% \\
\text { the total budget for fiscal year when is taken. }\end{array}$ & No & Ambiguos & No & No \\
\hline Michoacán & Yes & Yes & $\begin{array}{l}\text { Debt service in any case should be greater than } \\
2.5 \% \text { of the annual budget for the fiscal year debt } \\
\text { is taken and should be based on financial } \\
\text { projections. }\end{array}$ & Yes & Yes & No & No \\
\hline Morelos & Yes & No & $\ldots$ & No & No & Yes & Yes \\
\hline Nayarit & Yes & Yes & $\begin{array}{l}\text { The debt service in any case should be greater } \\
\text { than } 15 \% \text { of the annual budget for the fiscal year } \\
\text { the debt is taken and there should be a projected } \\
\text { superavit of the primary deficit. }\end{array}$ & No & Ambiguos & No & No \\
\hline Nuevo León & Yes & No & $\ldots$ & Yes & Yes & No & No \\
\hline Oaxaca & Yes & No & $\ldots$ & No & No & No & No \\
\hline Puebla & Yes & No & $\ldots$ & No & Ambiguos & Yes & Yes \\
\hline Querétaro & Yes & No & $\ldots$ & Yes & Yes & No & No \\
\hline Quintana Roo & Yes & No & $\ldots$ & Yes & Yes & No & No \\
\hline San Luis Potosí & Yes & Yes & $\begin{array}{l}\text { Debt cannot be higher than } 20 \% \text { of authorized } \\
\text { revenues in annual budget. }\end{array}$ & n.a. & n.a. & n.a. & n.a. \\
\hline Sinaloa & Yes & No & $\begin{array}{l}\text { Short term obligations will not constitute debt } \\
\text { unless the cumulative balance exceeds } 5 \% \text { of } \\
\text { fiscal years revenue. }\end{array}$ & No & No & Yes & Yes \\
\hline Sonora & Yes & No & $\ldots$ & Yes & Yes & No & No \\
\hline Tabasco & Yes & Yes & $\begin{array}{l}\text { Debt may be contracted if it doesn't exceed } 5 \% \text { of } \\
\text { state revenues in the fiscal year and debt is paid } \\
\text { out within the same fiscal year. Same terms for } \\
\text { municipalities. }\end{array}$ & Yes & Yes & Yes & Yes \\
\hline Tamaulipas & Yes & No & Debt ceiling only applied to short term debt. & No & Ambiguos & Yes & No \\
\hline Tlaxcala & Yes & No & $\ldots$ & & & & \\
\hline Veracruz & Yes & No & $\ldots$ & No & Ambiguos & No & No \\
\hline Yucatán & Yes & No & $\begin{array}{l}\text { Debt ceiling only applied to municipal debt. } \\
\text { Payment of obligations should not exceed more } \\
\text { than } 30 \% \text { of the annual federal revenue sharing. }\end{array}$ & Yes & Yes & Yes & Yes \\
\hline Zacatecas & Yes & No & $\ldots$ & n.a. & n.a. & n.a. & n.a. \\
\hline
\end{tabular}

Source: Author's work based on information from Fitch (2011c) and ASF (2011). 


\section{WORKING PAPERS}

The full series of Economics Department Working Papers can be consulted at www.oecd.org/eco/workingpapers/

1077. Deleveraging: challenges, progress and policies

(August 2013) by Romain Bouis, Ane Kathrine Christensen and Boris Cournède

1076. Policies to support sustainable long-term growth in New Zealand

(July 2013) by Calista Cheung

1075. Do structural policies affect macroeconomic stability?

(July 2013) by Volker Ziemann

1074. A simple fiscal stress testing model - case studies of Austrian, Czech and German economies (July 2013) by Ondra Kamenik, Zdenek Tuma, David Vavra and Zuzana Smidova

1073. Road connectivity and the border effect: evidence from Europe

(July 2013) by Henrik Braconier and Mauro Pisu

1072. Fiscal consolidation across government levels. Part 3: Intergovernmental grants, pro- or counter-cyclical?

(July 2013) by Hansjörg Blöchliger and Balázs Égert

1071. Fiscal consolidation across government levels. Part 2: Fiscal rules for sub-central governments, update of the institutional indicator

(July 2013) by Kaja Fredriksen

1070. Fiscal consolidation across government levels. Part 1: How much, what policies?

(July 2013) by Hansjörg Blöchliger

1069. Restructuring the electricity sector and promoting green growth in Japan

(June 2013) by Randall S. Jones and Myungkyoo Kim

1068. Labour market policies to promote growth and social cohesion in Korea

(June 2013) by Randall S. Jones and Satoshi Urasawa

1067. Education reform in Korea

(June 2013) by Randall S. Jones

1066. Belgium: enhancing the cost efficiency and flexibility of the health sector to adjust to population ageing

(June 2013) by Stéphane Sorbe

1065. Italy and the euro area crisis: securing fiscal sustainability and financial stability

(June 2013) by Oliver Denk

1064. Policy implementation in Italy: legislation, public administration and the rule of law (June 2013) by Paul O’Brien 
1063. Greening growth in Luxembourg

(June 2013) by Nicola Brandt

Vers une croissance plus verte en Luxembourg

(juin 2013) par Nicola Brandt

1062. The post-crisis narrowing of international imbalances - cyclical or durable?

(June 2013) by Patrice Ollivaud and Cyrille Schwellnus

1061. Restructuring welfare spending in Slovenia

(June 2013) by Rafał Kierzenkowski

1060. The economics of civil justice: new cross-country data and empirics

by G. Palumbo; G. Giupponi; L. Nunziata and J. Mora-Sanguinetti (forthcoming)

1059. Banks' restructuring and smooth deleveraging of the private sector in Slovenia

(June 2013) by Olena Havrylchyk

1058. Assessing the efficiency of welfare spending in Slovenia with data envelopment analysis (June 2013) by Matevz Hribernik and Rafał Kierzenkowski

1057. Policy determinants of school outcomes under model uncertainty: evidence from South Africa (June 2013) by Thomas Laurent, Fabrice Murtin, Geoff Barnard, Dean Janse van Rensburg, Vijay Reddy, George Frempong and Lolita Winnaar

1056. Improving education quality in South Africa

(June 2013) by Fabrice Murtin

1055. The 90\% public debt threshold: the rise and fall of a stylised fact

(June 2013) by Balázs Égert

1054. Challenges to sustain Poland's growth model

(June 2013) by Balázs Égert and Rafał Kierzenkowski

1053. Reforming agriculture and promoting Japan's integration in the world economy

(May 2013) by Randall S. Jones and Shingo Kimura

1052. Inequality and poverty in the United States: public policies for inclusive growth

(May 2013) by Oliver Denk, Robert Hagemann, Patrick Lenain and Valentin Somma

1051. Fiscal federalism and its impact on economic activity, public investment and the performance of educational systems

(May 2013) by Hansjörg Blöchliger, Balázs Égert and Kaja Fredriksen

1050. Restoring Japan's fiscal sustainability

(May 2013) by Randall S. Jones and Satoshi Urasawa

1049. Measuring total factor productivity at the firm level using OECD-ORBIS

(May 2013) by Peter Gal

1048. A projection method for public health and long-term care expenditures

(June 2013) by Christine de la Maisonneuve and Joaquim Oliveira Martins 